\title{
Original paper \\ Metamorphic evolution of the contact aureole of the Dipilto Batholith, Eastern Chortis Terrane, Nicaragua
}

\author{
David BURIÁNEK*, Zdeněk DOLNÍČEK² \\ ${ }^{1}$ Czech Geological Survey, Leitnerova 22, 65859 Brno, Czech Republic; david.burianek@geology.cz \\ ${ }^{2}$ Department of Geology, Faculty of Science, Palacký University, tř. 17. listopadu 12, 77146 Olomouc, Czech Republic; \\ dolnicek@prfnw.upol.cz \\ * Corresponding author
}

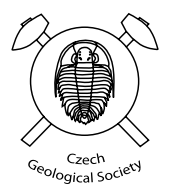

\begin{abstract}
We examined the tectono-metamorphic evolution of the contact aureole around the Cretaceous Dipilto Batholith in the Eastern Chortis Terrane (Nicaragua, Central America). Three distinct metamorphic phases were distinguished. The first phase represented greenschist-facies regional metamorphism $\left(\mathrm{M}_{1}\right)$ accompanied by a prograde deformation $\left(\mathrm{D}_{1}\right)$. The Cretaceous contact-metamorphic event $\left(\mathrm{M}_{2}\right)$ produced the peak-metamorphic mineral assemblages Wo $+\mathrm{Di}+\mathrm{Grs}+$ $\mathrm{Ves}+\mathrm{Qtz}+\mathrm{Pl}+\mathrm{Kfs}$ in the calc-silicate rocks and $\mathrm{Bt}+\mathrm{Qtz}+\mathrm{Ab}+\mathrm{And} \pm \mathrm{Crd} \pm \mathrm{Gr} \pm \mathrm{Chl} \pm \mathrm{Ms} \pm \mathrm{Kfs}$ in the metapelites The estimated $\mathrm{P}-\mathrm{T}$ conditions near the contact with granitoids are $500-650^{\circ} \mathrm{C}$ and $\sim 0.2 \mathrm{GPa}$ and coexisting fluids were relatively poor in $\mathrm{CO}_{2}\left(\mathrm{X}_{\mathrm{CO}_{2}}\right.$ below 0.15$)$. The emplacement of the Dipilto Batholith at shallow crustal levels was rarely accompanied by weak deformation of the metasediments $\left(\mathrm{D}_{2}\right)$. During cooling and exhumation, the contact aureole was locally affected by deformation $\left(\mathrm{D}_{3}\right)$ and retrograde metamorphism $\left(\mathrm{M}_{3}\right)$ again under greenschist-facies conditions.
\end{abstract}

Keywords: low-pressure metamorphism, fluid inclusions, calc-silicate rocks, Dipilto Batholith, Nicaragua, Eastern Chortis Terrane Received: 21 October 2010; accepted: 23 February 2011; handling editor: J. Kotková

\section{Introduction}

The emplacement of granitic intrusions causes textural, chemical and mineralogical changes of the wall rock producing a metamorphic aureole. The main changes occur in the immediate vicinity due to temperature perturbation during crystallization and cooling of the magmatic rocks. The mineralogical and textural transformations of metamorphic rocks are function of the distance from the contact with the pluton, the chemical composition of the protolith, temperature of the intruding magma, and permeability of the wall rock. Significant agent can be also the composition of the fluid phase coexisting with the rocks in the contact aureoles.

Calc-silicate rocks (skarns) containing wollastonite and vesuvianite are common constituents of many highgrade contact aureoles. Wollastonite and vesuvianite are typical products of interaction of carbonate rocks with water-rich magmatic fluids (Hochella et al. 1982; Gerdes and Valley 1994), and were used for interpretation of the fluid evolution during contact metamorphism (Ferry et al. 2001; Rossetti et al. 2007). However, the sensitivity of calc-silicate rocks to changes in the fluid composition requires determination of one of three main independent variables (the activity of $\mathrm{CO}_{2}, \mathrm{~T}$ or $\mathrm{P}$ ).

Combining information from the fluid inclusions together with $\mathrm{P}-\mathrm{T}-\mathrm{X}_{\mathrm{CO}_{2}}$ conditions estimated from the mineral assemblages of calc-silicate rocks and surrounding metapelite enabled the interpretation of metamorphic evolution of rocks in the contact aureole of the Dipilto Batholith, northern Nicaragua, presented in the current paper.

\section{Geological setting}

Our work has focused on the metamorphic evolution of the contact aureole of the Dipilto Batholith in the eastern part of the Chortis Block. The Chortis Block (Dengo 1969; Case et al. 1990) is situated in the northern part of Central America (Honduras, Nicaragua, El Salvador, Guatemala). Its northern boundary is formed by the Maya Block (Dengo 1969) and the southeastern by the Siuna Terrane (Venable 1994). The Chortis Block (Fig. 1a) can by subdivided into four tectonic terranes (Rogers et al. 2007a). (1) Central Chortis Terrane consists of a Grenvillean to Paleozoic ( $1 \mathrm{Ga}$ to $222 \mathrm{Ma}$ ) metamorphic basement partially covered by Mesozoic to Cenozoic sediments and volcanic rocks. Metamorphic rocks including phyllite, gneiss and orthogneiss underwent greenschist- to amphibolite-facies metamorphism. (2) Northern Chortis Terrane has a similar lithology, but is cut by intrusions of plutonic rocks of the Late Cretaceous and Palaeocene age, and modified by the associated contact metamorphism. (3) Southern Chortis Terrane is composed of crystalline rocks and is overlain by Miocene pyroclastic and volcanic rocks. (4) Eastern Chortis Terrane is dominated by Jurassic phyllite metamorphosed under 


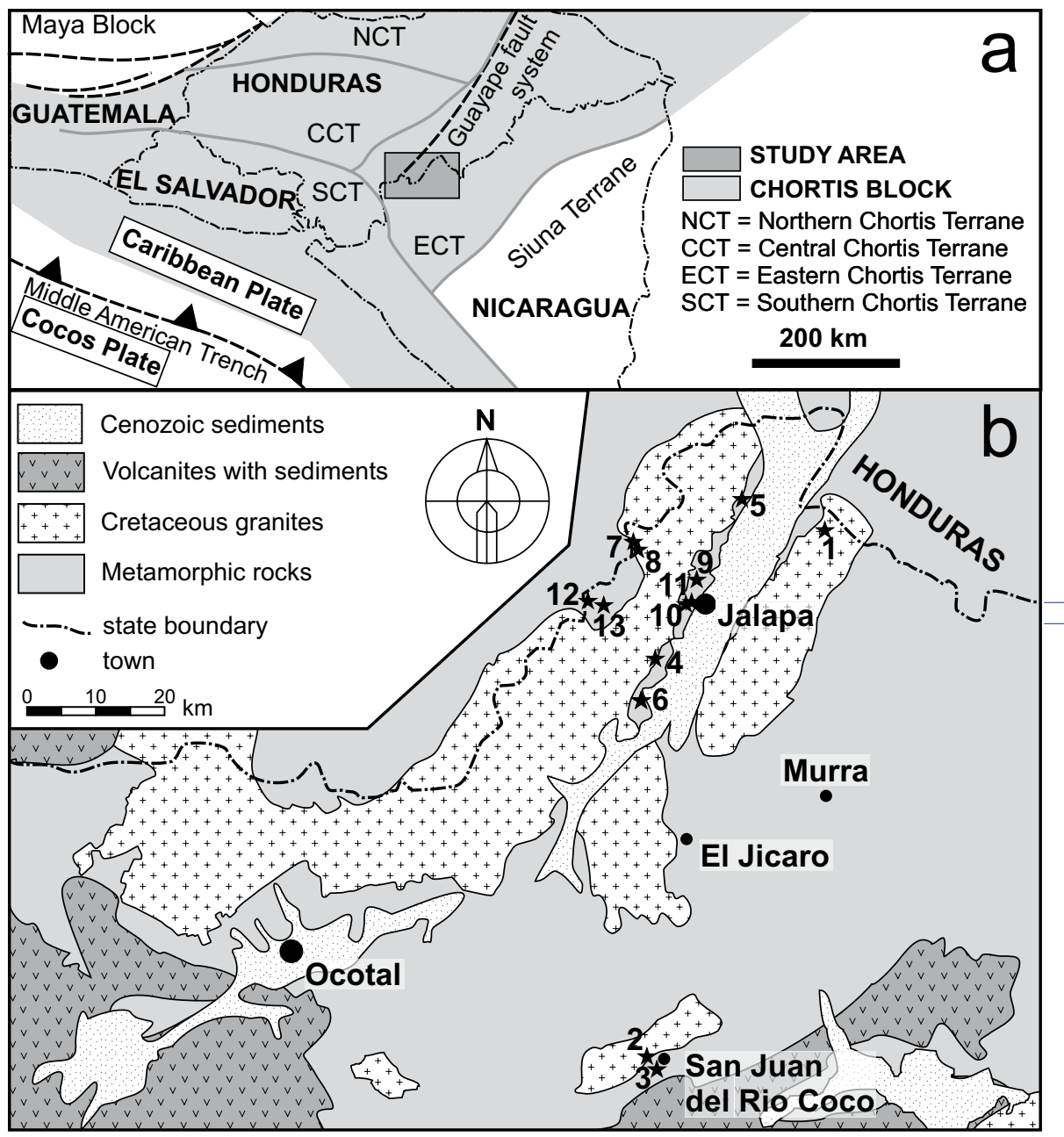

Fig. 1a Tectonic setting of northern Central America showing the terranes making up the Chortis Block. b - Simplified geological map of the northeastern Nicaragua with sample locations (Tab. 1). Modified after Rogers (2003), Žáček and Hradecký (2005), Rogers et al. (2007b) and Buriánek et al. (2010). greenschist-facies conditions and intruded by Cretaceous plutonic rocks.

The Eastern Chortis Terrane represents the rifted continental margin of the North American Plate developed during the Jurassic separation of the North and South American plates. It is built by a metasedimentary sequence overlying the basement, all intruded by Cretaceous igneous bodies. The metasediments are interpreted as a metamorphosed lithological equivalent of the Agua Fría Formation (Viland et al. 1996). The Middle Jurassic Agua Fría Formation (part of the Honduras Group) is at least 1700 meters thick and consists of metamorphosed and unmetamorphosed coastal plain fluvial deposits, minor shallow-marine carbonates, and rhythmically-bedded siliciclastic sedimentary rocks interpreted as marine turbidites (Ritchie and Finch 1985; Rogers 2003). Based on the observation of the transition of unmetamorphosed into a slightly metamorphosed equivalent, Rogers et al. (2007b) attributed the Agua Fría Formation, together with isolated exposures of Paleozoic metasedimentary sequences (Nueva Segovia and Cacaguapa Group; Ortega-Gutiérrez et al. 2007), to the basement of the Eastern Chortis Terrane.
The Dipilto Batholith (Fig. 1b), covering an area of c. $800 \mathrm{~km}^{2}$, is one of the large plutonic bodies in the Eastern Chortis Terrane. It is elongated in NE-SW direction along the Nicaragua-Honduras state boundary. The main part is situated between the towns of Ocotal and Jalapa in the district of Nueva Segovia (northern Nicaragua). The modal composition of the plutonic rocks ranges from amphibole-biotite tonalite to biotite and cordierite-biotite granite to granodiorite (Fig. 2a) and subordinate amphibole gabbros to diorites. The granitoids can be interpreted as a result of collision between the Guerrero-Caribbean Arc and the continental margin of the Southern Chortis Block (Rogers et al. 2007b). The radiometric dating indicates a Cretaceous intrusion age of the Dipilto Batholith (Rb-Sr whole-rock ages $83 \pm 3 \mathrm{Ma}$, Zoppis-Bracci and Del Giudice 1961 and $140 \pm 15$ Ma, Donnelly et al. 1990; $\mathrm{K}-\mathrm{Ar}$ ages $110 \pm 1.2 \mathrm{Ma}$ on biotite and $115 \pm 1.5 \mathrm{Ma}$ on hornblende, Hodgson 2000).

This intrusive body is surrounded by contact aureole several $\mathrm{km}$ wide. The main metamorphic rocks therein are graphitic metapelites with layers of metapsammite, several $\mathrm{mm}$ to $\mathrm{dm}$ thick. In addition, layers and bodies 

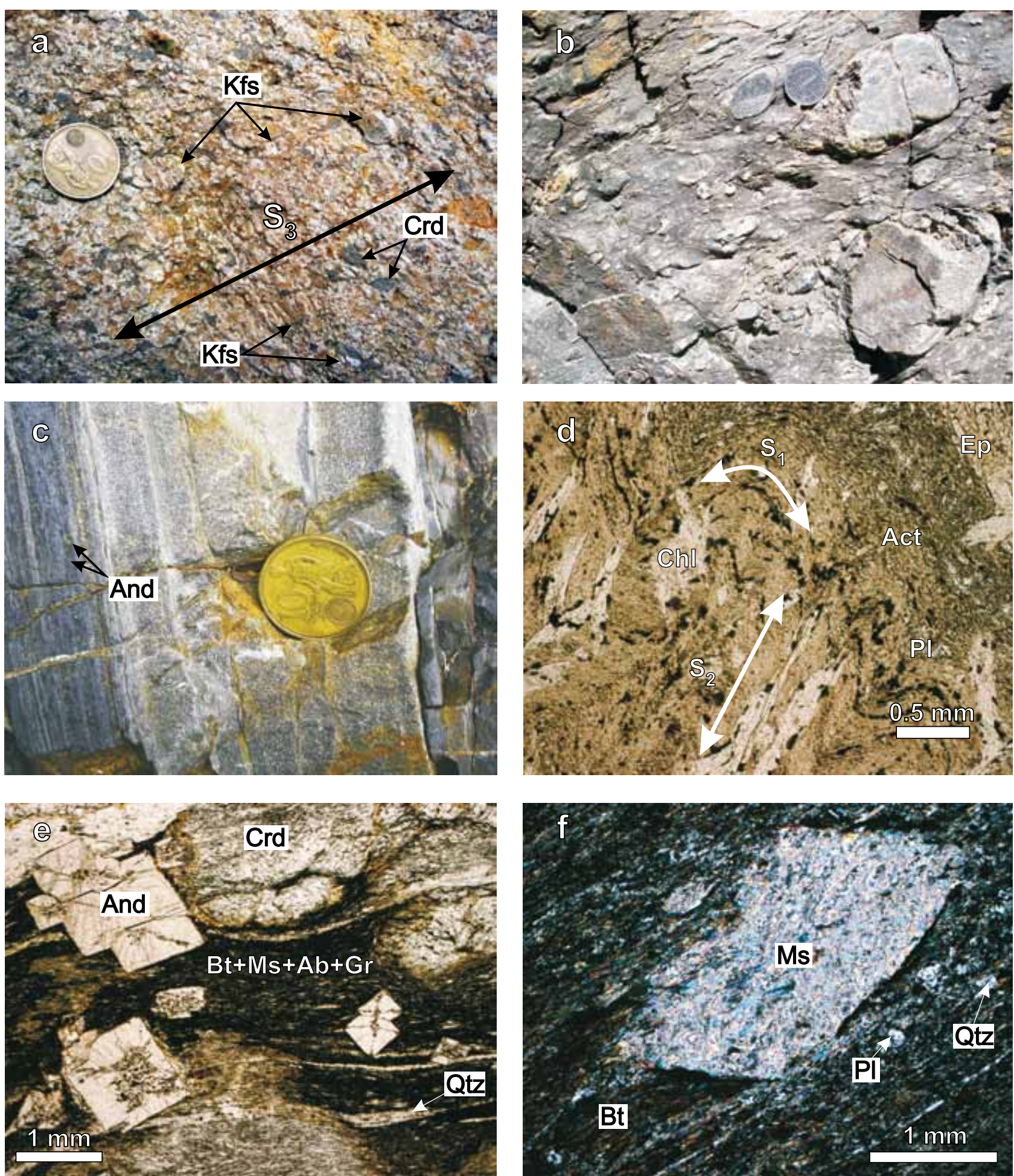

Fig. 2 Typical textures of granitoids of the Dipilto Batholith and metamorphic rocks from the Agua Fría Formation: a - Preferred orientation of feldspar phenocrysts indicating some subsolidus deformation $\left(\mathrm{D}_{3}\right)$ in the biotite-cordierite granodiorite (sample D016); $\mathbf{b}-$ Outcrop of metaconglomerates with deformed small pebbles of quartz and acid volcanites (sample D003B); c - Layer of metapsammite (Qtz + Fsp) in the andalusite-cordierite schist with andalusite porphyroblasts (sample D107); d - Greenschist (actinolite + albite + epidote + quartz + chlorite); long axes of chlorite porphyroblasts are aligned at an angle to axial plane of the main crenulation (sample D004); $\mathbf{e}$-Andalusite-cordierite schist with post-tectonic andalusite porphyroblasts, sample D107 (plane-polarized light); $\mathbf{f}-$ Muscovite pseudomorph after andalusite in schist (Ms $+\mathrm{Bt}+$ $\mathrm{Qtz}+\mathrm{Ab}+\mathrm{Gr}$ ), sample D027 (crossed polars) 
of metavolcanites, metaconglomerates, quartzites and calc-silicate rocks occur locally. Relics of sedimentary textures, such as lamination, small pebbles in metaconglomerate (Fig. 2b), bedding and/or positive gradation in metapsammitic layers in the western part of the studied area (Fig. 2c) are often preserved. The contact-metamorphic assemblage developed in graphitic metapelites is relatively simple: cordierite + biotite +graphite \pm muscovite \pm K-feldspar \pm andalusite \pm chlorite.

According to Rogers (2003), the metamorphic rocks in the studied area belong to the Middle Jurassic Agua Fría Formation (part of the Honduras Group). Similarly Viland et al. (1996) documented regional deformation and metamorphism in a part of the Agua Fría Formation in the Late Jurassic times, prior to Cretaceous sedimentation. In contrast, other authors (e.g. Figge 1966; Hradecký et al. 2005) interpreted the rocks in the contact aureole of the Dipilto Batholith as the part of the Nueva Segovia Paleozoic metasedimentary sequences. On the basis of lithological similarities with metamorphic rocks of the Agua Fría Formation in Honduras and presence of relict sedimentary structures in metamorphic rocks, we prefer the first possibility, although no direct evidence such as transition from sediments to metasediments has been observed.

\section{Methods}

We selected 12 samples representing typical rocks of contact aureole of the Dipilto Batholith and one amphibolebiotite granodiorite (Tab. 1). Mineral analyses were performed with a Cameca SX-100 electron microprobe at the Joint Microprobe Laboratory of the Masaryk University and Czech Geological Survey in Brno. The measurements were carried out in a wave-dispersion mode under the following conditions: $15 \mathrm{kV}$ acceleration voltage, $5 \mu \mathrm{m}$ electron beam diameter, $30 \mathrm{nA}$ beam current and $20 \mathrm{~s}$ counting time. Augite $(\mathrm{Si}, \mathrm{Mg})$, orthoclase $(\mathrm{K})$, jadeite $(\mathrm{Na})$, chromite $(\mathrm{Cr})$, almandine $(\mathrm{Al})$, andradite $(\mathrm{Fe}, \mathrm{Ca})$, rhodonite $(\mathrm{Mn})$, and $\mathrm{TiO}(\mathrm{Ti})$ were used as standards. The empirical formulae of cordierite, feldspars and micas were recalculated to 18,8 and 22 oxygen atoms, respectively. The structural formulae of tourmalines were calculated on the basis of 31 anions, under the assumption of a stoichiometric amount of $\mathrm{H}_{2} \mathrm{O}$ as $(\mathrm{OH})$ - (i.e., $\mathrm{OH}+\mathrm{F}=4$ apfu, atoms per formula unit), and $\mathrm{B}_{2} \mathrm{O}_{3}$ with $\mathrm{B}=3 \mathrm{apfu}$ ). The crystallochemical formulae of garnet were obtained on the basis of 12 oxygen atoms; the ferric iron was recalculated based on charge balance and stoichiometry. The crystallochemical formulae of vesuvianite were obtained on the basis of 78 anions. Pyroxenes are classified according to Morimoto et al. (1988); the formulae were obtained on the basis of 4 cations and the method for estimating the ferric iron given by Droop (1987). The amphibole formulae were calculated on the basis of 23 oxygen atoms; all analyses can be classified as calcic amphiboles (Leake et al. 1997). The $\mathrm{Fe}^{2+} / \mathrm{Fe}^{3+}$ ratios were estimated on the basis of cation total of 13 excluding $\mathrm{Ca}, \mathrm{Na}$ and $\mathrm{K}$ (13 eCNK). The abbreviations of mineral names used in the text correspond to Kretz (1983).

Samples of at least 3-4 kg were used for whole-rock chemical analyses. Major and trace elements were determined by Acme Analytical Laboratories, Vancouver, Canada. Major oxides were analysed by the ICP-MS method. Loss on ignition (LOI) was calculated from the weight difference after ignition at $1000{ }^{\circ} \mathrm{C}$. The rare earth and other trace elements were analysed by INAA and ICP-MS following $\mathrm{LiBO}_{2}$ fusion. Geochemical data were recalculated using the GCDkit software package (Janoušek et al. 2006).

The equilibrium positions of the calc-silicate rock within the $\mathrm{P}-\mathrm{T}-\mathrm{X}_{\mathrm{CO}_{2}}$ space were calculated using version

Tab. 1 List of samples (granodiorite and thermally-metamorphosed rocks), their locations and mineral assemblages

\begin{tabular}{|c|c|c|c|c|c|c|}
\hline No. & Sample & $\begin{array}{c}\text { Longitude } \\
\left({ }^{\circ} \mathrm{E}\right)\end{array}$ & $\begin{array}{l}\text { Latitude } \\
\left({ }^{\circ} \mathrm{N}\right)\end{array}$ & Rock & Mineral assemblage & $\begin{array}{l}\text { Approximate distance } \\
\text { from the contact }\end{array}$ \\
\hline 1 & H056 & $86^{\circ} 01^{\prime} 36.3^{\prime \prime}$ & $13^{\circ} 56^{\prime} 18.4^{\prime \prime}$ & Granodiorite & $\mathrm{Pl}+\mathrm{Qtz}+\mathrm{Kfs}+\mathrm{Bt}+\mathrm{Amp}$ & - \\
\hline 2 & D003 & $86^{\circ} 12^{\prime} 25.4^{\prime \prime}$ & $13^{\circ} 32^{\prime} 56.3^{\prime \prime}$ & And schist & $\mathrm{Qtz}+\mathrm{Bt}+\mathrm{Ms}+\mathrm{Pl}+\mathrm{And}+\mathrm{Kfs}$ & $80 \mathrm{~m}$ \\
\hline 3 & D004 & $86^{\circ} 11^{\prime} 48.1^{\prime \prime}$ & $13^{\circ} 33^{\prime} 18.1^{\prime \prime}$ & Metatuff & $\mathrm{Act}+\mathrm{Pl}+\mathrm{Qtz}+\mathrm{Chl}+\mathrm{Ep}$ & $1300 \mathrm{~m}$ \\
\hline 4 & D016 & $86^{\circ} 09^{\prime} 53.8^{\prime \prime}$ & $13^{\circ} 52^{\prime} 32.5^{\prime \prime}$ & And schist & $\mathrm{Qtz}+\mathrm{Pl}+\mathrm{Gr}+\mathrm{Chl}+\mathrm{Ms}+\mathrm{Kfs}(\mathrm{Ms}$ replaces And, $\mathrm{Kfs})$ & $10 \mathrm{~m}$ \\
\hline 5 & D027 & $86^{\circ} 05^{\prime} 36.3^{\prime \prime}$ & $14^{\circ} 00^{\prime} 13.4^{\prime \prime}$ & And-Crd schist & $\begin{array}{l}\mathrm{Crd}+\mathrm{And}+\mathrm{Qtz}+\mathrm{Pl}+\mathrm{Gr}+\mathrm{Ms} \\
(\mathrm{Chl}+\mathrm{Ms} \text { replace Crd, Ms replaces And })\end{array}$ & $100 \mathrm{~m}$ \\
\hline 6 & D031 & $86^{\circ} 06^{\prime} 43.6^{\prime \prime}$ & $14^{\circ} 00^{\prime} 01.2^{\prime \prime}$ & Calc-silicate rock & $\mathrm{Wo}+\mathrm{Ves}+\mathrm{Di}+\mathrm{Qtz}+\mathrm{Fsp}+\mathrm{Cal}$ & $20 \mathrm{~m}$ \\
\hline 7 & D059 & $86^{\circ} 10^{\prime} 54.1^{\prime \prime}$ & $13^{\circ} 58^{\prime} 06.9^{\prime \prime}$ & And schist & $\mathrm{Qtz}+\mathrm{Pl}+\mathrm{Crd}+\mathrm{And}+\mathrm{Gr}+\mathrm{Bt}+\mathrm{Ms}+\mathrm{Tur}$ & $600 \mathrm{~m}$ \\
\hline 8 & D062 & $86^{\circ} 10^{\prime} 46.9^{\prime \prime}$ & $13^{\circ} 57^{\prime} 48.1^{\prime \prime}$ & And-Crd schist & $\mathrm{Qtz}+\mathrm{Pl}+\mathrm{Ms}+\mathrm{Bt}+\mathrm{Chl}+\mathrm{Gr}+\mathrm{Crd}+\mathrm{And}$ & $500 \mathrm{~m}$ \\
\hline 9 & D076 & $86^{\circ} 07^{\prime} 35.9^{\prime \prime}$ & $13^{\circ} 55^{\prime} 51.1^{\prime \prime}$ & Crd schist & $\mathrm{Qtz}+\mathrm{Ms}+\mathrm{Bt}+\mathrm{Pl}+\mathrm{Chl}+\mathrm{Gr}(\mathrm{Chl}+\mathrm{Ms}$ replace $\mathrm{Crd})$ & $900 \mathrm{~m}$ \\
\hline 10 & D078 & $86^{\circ} 08^{\prime} 17.8^{\prime \prime}$ & $13^{\circ} 55^{\prime} 12.8^{\prime \prime}$ & Crd schist & $\mathrm{Crd}+\mathrm{Qtz}+\mathrm{Pl}+\mathrm{Ms}+\mathrm{Bt}+\mathrm{Chl}+$ Tur & $800 \mathrm{~m}$ \\
\hline 11 & H079 & $86^{\circ} 08^{\prime} 06.9^{\prime \prime}$ & $13^{\circ} 55^{\prime} 15.9^{\prime \prime}$ & Amphibolite & $\mathrm{Amp}+\mathrm{Qtz}+\mathrm{Pl}+\mathrm{Mgt}$ & $30 \mathrm{~m}$ \\
\hline 12 & D105 & $86^{\circ} 13^{\prime} 12.6^{\prime \prime}$ & $13^{\circ} 55^{\prime} 24.0^{\prime \prime}$ & Metarhyolite & $\mathrm{Qtz}+\mathrm{Pl}+\mathrm{Kfs}+\mathrm{Bt}+\mathrm{Ms}$ & $3000 \mathrm{~m}$ \\
\hline 13 & D107 & $86^{\circ} 12^{\prime} 27.3^{\prime \prime}$ & $13^{\circ} 55^{\prime} 07.9^{\prime \prime}$ & And-Crd schist & $\mathrm{Qtz}+\mathrm{Ms}+\mathrm{Kfs}+\mathrm{Bt}+\mathrm{Crd}+\mathrm{And}+\mathrm{Gr}$ & $90 \mathrm{~m}$ \\
\hline
\end{tabular}


2.75 of the THERMOCALC computer program (Holland and Powell 1998) with the dataset of Holland and Powell (1990). The principal multivariant reactions were constrained in the low-variance assemblage with the activities of the mineral end-members calcite + clinopyroxene + quartz + grossular + anorthite + wollastonite + vesuvianite $+\mathrm{H}_{2} \mathrm{O}+\mathrm{CO}_{2}$. Activities were obtained using the AX program of Holland and Powell (1998). The T- $\mathrm{X}_{\mathrm{CO}_{2}}$ diagram for a pressure of $0.2 \mathrm{GPa}$ was constructed for core compositions of grossular $(\mathrm{a}=0.73 \pm 0.15)$, diopside $(\mathrm{a}=0.59 \pm 0.05)$ and calcite $(\mathrm{a}=0.99 \pm 0.05)$. For other components, the activities of the end-member components (anorthite, vesuvianite, quartz) were used. Albite in the calc-silicate rocks, as the product of recrystallization of ternary feldspar, was not considered.

The pseudosection for a selected sample (D027) of contact-metamorphosed schist was calculated using the PERPLEX program (Connolly 1990). The assemblages were computed using VERTEX (Connolly 1990) with end-member data and solution models from Holland and Powell (1998) and the solution model for plagioclase from Newton et al. (1980).

Fluid inclusions (FI) have been studied petrographically and microthermometrically in a standard doubly polished plate. Recognition of individual genetic types of FI was performed according to the criteria described in the literature (Roedder 1984; Shepherd et al. 1985). Microthermometric parameters were obtained using a Linkam THMSG 600 heating-freezing stage mounted on an Olympus BX-51 microscope. The stage was calibrated using inorganic standards and fluid inclusions with known phase transition temperatures. The following parameters were measured: eutectic temperature $\left(\mathrm{T}_{\mathrm{e}}\right)$, melting temperature of the last ice $\left(\mathrm{T}_{\text {m-ice }}\right)$, melting temperature of clathrate $\left(\mathrm{T}_{\mathrm{m} \text {-cla }}\right)$, and temperature of total homogenization $\left(\mathrm{T}_{\mathrm{h} \text {-tot }}\right)$. Interpretation of the microthermometric data (composition, densities and isochores) was performed using the FLUIDS software package (Bakker 2003).

\section{Deformation}

Three main phases of ductile deformation were distinguished in the metapelites. The first deformation phase $\left(D_{1}\right)$ was related to the low-grade regional metamorphism (Hradecký et al. 2005). A $S_{1}$ foliation is defined by parallel arrangement of sericite and/or chlorite flakes in phyllites and greenschists. This syn-metamorphic foliation dips gently $\left(20-30^{\circ}\right)$ or steeply $\left(60-80^{\circ}\right)$ to the SE-NE and NW-SW (Hradecký et al. 2005; Žáček and Hradecký 2005; Buriánek et al. 2010) and was caused by $D_{1}$ (Fig. 3a). The foliation is often oriented parallel or sub-parallel to the bedding planes. Stretching lineations plunge mainly to the NNE and SSW at $2-35^{\circ}$ (Fig. 3a). The metapelites are locally mesoscopically to megascopically folded with flat-dipping axial planes parallel to the lineation. Younger kink folds with fold axes oriented NNW-SSE reaching several dozens centimetres in size were observed mainly in the metapelites of the eastern part of the studied area.

In the contact aureole, LP mineral assemblages $\mathrm{M}_{2}$ developed with the peak mineral assemblages that are as a rule post-tectonic (Martens et al. 2007). However, $S_{2}$ foliation steeply to moderately dipping to the ESE or WNW (Fig. 3a), defined by the alignment of muscovite, biotite or chlorite, affected some metapelites and metavolcanites in the contact aureole around the Dipilto Batholith. The long axes of andalusite porphyroblasts present in the rocks are oriented parallel to $\mathrm{S}_{2}$, however often without any preferential linear orientation (randomly oriented on the foliation plane). The relationship between foliations $\mathrm{S}_{1}$ and $\mathrm{S}_{2}$ is clearly visible in the contact aureole of a small satellite body near San Juan del Río Coco (Fig. 1b). In the marginal part of the contact aureole, regional foliation $\mathrm{S}_{1}$ is deflected by $\mathrm{S}_{2}$. Locally, foliation $\mathrm{S}_{2}$ developed parallel to the axial plane of crenulation folds bending $S_{1}$ (Fig. 2d). Calc-silicate rocks form boudins parallel with the $\mathrm{S}_{1}$ foliation of the surrounding metapelites.

The Dipilto Batholith locally contains a magmatic foliation oriented $\sim$ NNW-SSE defined by aligned igneous minerals (mainly biotite and feldspars) and enclaves. The subsolidus deformation of the granitoids is indicated by the dynamic recrystallization of quartz into aggregates of new subgrains. Subsolidus foliation is oriented $\sim$ NNW-SSE with steep inclination to the E-NE (Fig. 3). This $\mathrm{S}_{3}$ foliation is observed only within, or adjacent to, the shear zones.

Small veins oriented perpendicularly to the main foliation are common in the calc-silicate rocks. Older veins consist of vesuvianite, grossular-rich garnet, quartz and minor wollastonite. Younger veins are commonly filled with quartz.

The Jalapa Graben is NE-SW oriented depression, filled by Cenozoic clastic sediments (sands with intercalations of the clays), between village of El Jicaro and Nicaragua-Honduras state boundary (up to $5 \mathrm{~km}$ wide and $\sim 35 \mathrm{~km}$ long). The youngest structures observed in the field are brittle faults (Fig. 3b). The NNE-SSW oriented steep faults are roughly parallel to the major Jalapa Graben. These normal, rare dextral faults are parallel to the Guayape fault system (Fig. 1b). Dextral and rare sinistral steep faults striking in the WNW-ESE direction are younger than the faults of the Jalapa Graben. The minor structures are represented by $\mathrm{E}-\mathrm{W}$ trending dextral faults. 

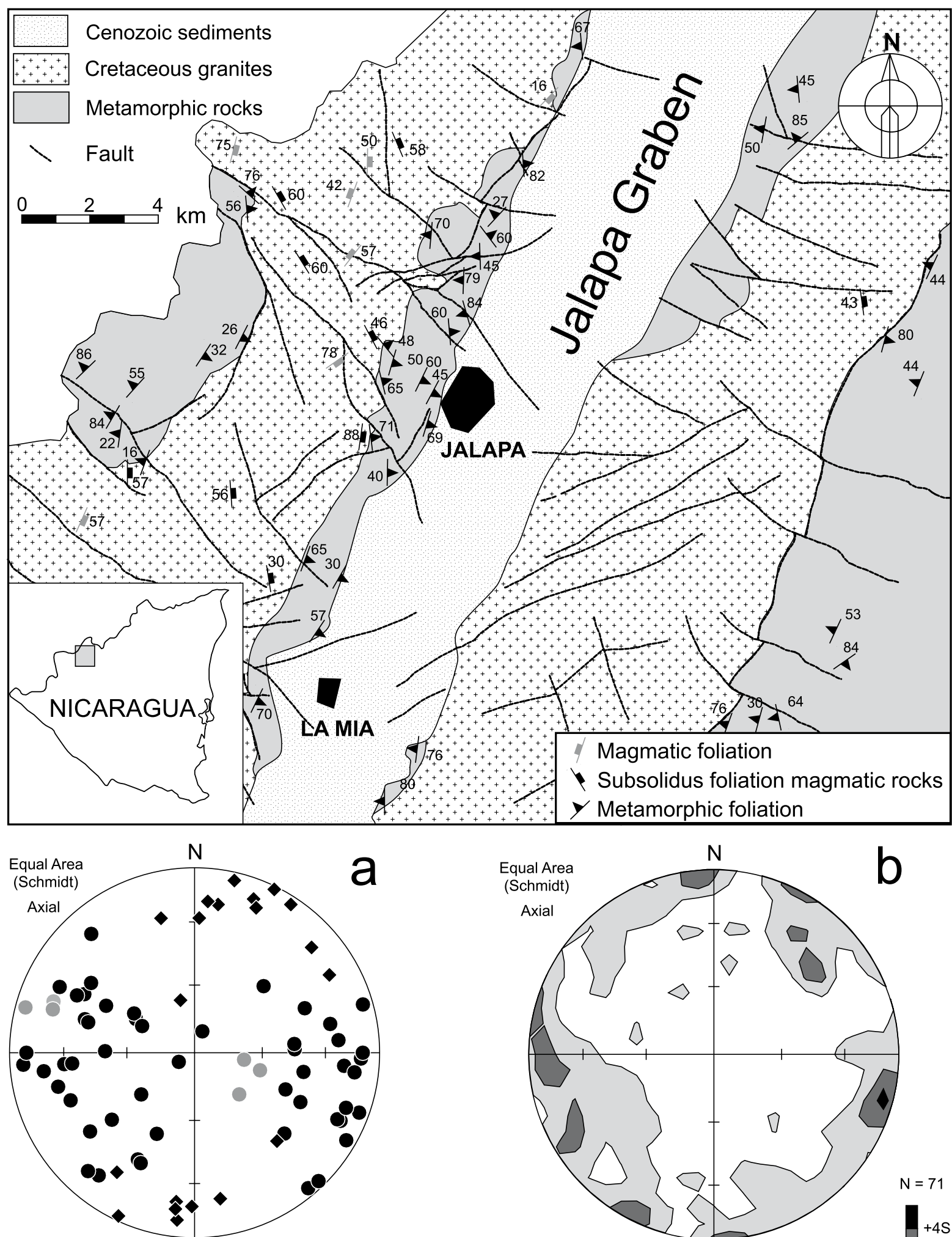

- metamorphic lineation $(\mathrm{N}=20)$

- metamorphic foliation $S_{1}(N=50)$

- metamorphic foliation $S_{2}(N=6)$

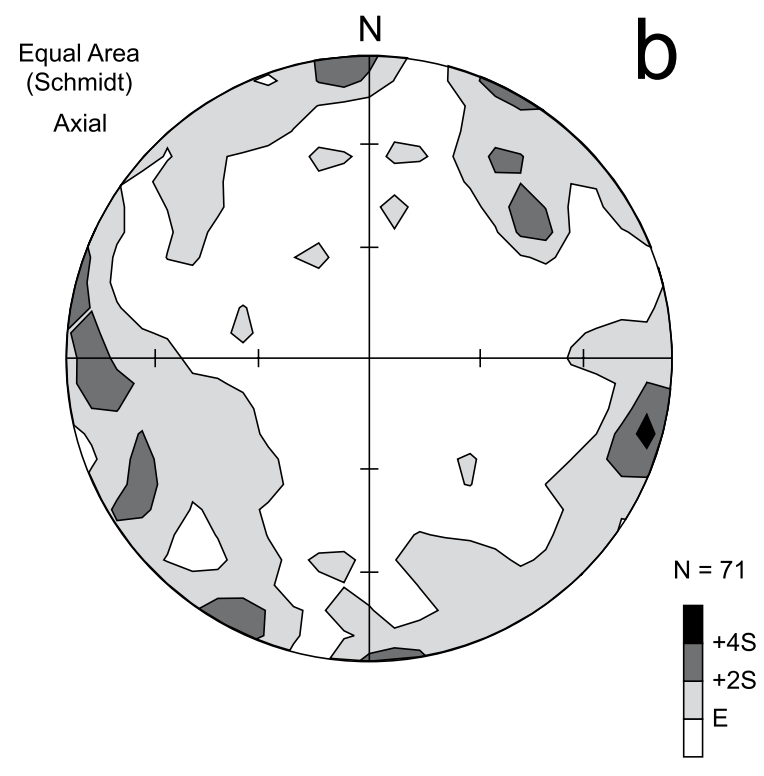

Fig. 3 Top - Simplified tectonic map of the foliation in the studied area around the town of Jalapa. Below - Schmidt equal-area stereograms: a - pole diagram of 56 measured metamorphic foliations and 20 metamorphic lineations; b - contoured stereogram of 71 main faults. 


\section{Petrography}

\subsection{Plutonic rocks of the Dipilto Batholith}

The Dipilto Batholith consists of several types of igneous rocks: amphibole and amphibole-biotite diorites-gabbros, biotite and amphibole-biotite granodiorites-tonalites which locally contain abundant $\mathrm{cm}-\mathrm{dm}$-sized mafic enclaves, porphyritic biotite granites to granodiorites locally with cordierite and/or tourmaline, medium-grained biotite to muscovite granites and leucogranites.

Mineral assemblages of the grey medium-grained, rarely porphyritic amphibole-biotite granodiorite to tonalite were used for the calculation of $\mathrm{P}-\mathrm{T}$ conditions of emplacement of Dipilto Batholith. Subhedral to euhedral plagioclase (35-49 vol. \%) is often oscillatory zoned and can contain boxy-cellular cores $\left(\mathrm{An}_{27-54}\right)$. Secondary clinozoisite, prehnite, scapolite and sericite partially replace the plagioclase core. Proportion of the anhedral quartz (25-31 vol. \%) and perthitic K-feldspar $\left(1-8\right.$ vol. $\left.\% ; \mathrm{Ab}_{4-8}\right)$ is variable (Tab. 2). Biotite flakes (8-14 vol. \%) are chemically homogeneous ( $\mathrm{Fe} /(\mathrm{Mg}+$ $\left.\mathrm{Fe})=0.53-0.54,{ }^{\mathrm{IV}} \mathrm{Al}=2.41-2.45 \mathrm{apfu}\right)$. Subhedral amphibole $(0-8$ vol. \%) is classified as magnesiohornblende
$(\mathrm{Mg} /(\mathrm{Mg}+\mathrm{Fe})=0.55-0.61, \mathrm{Si}=7.13-7.41 \mathrm{apfu}-$ Tab. 3) according to Leake et al. (1997). Accessory minerals (zircon, monazite and apatite) are commonly included in biotite.

\subsection{Low-grade metamorphic rocks outside the contact aureole (regional metamorphism)}

Low-grade metamorphic conditions characterize the large area between Jalapa, San Juan del Río Coco and Ocotal (Zoppis-Bracci 1957; Del Giuduce 1960; Engels 1964; Figge 1966; Hradecký et al. 2005; Blandino 2006; Quintero-Román 2006). Metasediments contain white mica (sericite), chlorite, quartz, albite and graphite. Metamorphic mineral assemblages in acid to basic metavolcanites consist of chlorite + actinolite + albite + epidote \pm quartz \pm white mica \pm prehnite \pm calcite \pm biotite \pm titanite \pm ilmenite \pm magnetite (Hradecký et al. 2005). Quartzite, metacarbonate and metaconglomerate locally form layers and boudins.

Crenulated greenschist crops out near San Juan del Río Coco (Fig. 1b). The studied sample D004 (Tab. 1) is

Tab. 2 Representative chemical compositions of plagioclase

\begin{tabular}{|c|c|c|c|c|c|c|c|}
\hline Sample & $\mathrm{D} 031 / 2$ & $\mathrm{D} 031 / 3$ & $\mathrm{D} 107 \mathrm{~A} / 4$ & $\mathrm{D} 107 \mathrm{~A} / 5$ & H056/1 & $\mathrm{H} 056 / 4$ & $\mathrm{H} 056 / 6$ \\
\hline $\mathrm{SiO}_{2}$ & 68.69 & 64.87 & 65.04 & 64.51 & 63.82 & 53.73 & 56.83 \\
\hline $\mathrm{P}_{2} \mathrm{O}_{5}$ & 0.00 & 0.00 & 0.14 & 0.39 & 0.03 & 0.00 & 0.00 \\
\hline $\mathrm{Al}_{2} \mathrm{O}_{3}$ & 19.49 & 18.10 & 21.97 & 18.50 & 17.91 & 27.97 & 26.67 \\
\hline $\mathrm{FeO}$ & 0.00 & 0.01 & 0.13 & 0.15 & 0.02 & 0.05 & 0.03 \\
\hline $\mathrm{CaO}$ & 0.69 & 0.06 & 2.90 & 0.03 & 0.00 & 11.22 & 9.35 \\
\hline $\mathrm{Na}_{2} \mathrm{O}$ & 11.28 & 0.27 & 10.28 & 0.71 & 0.48 & 5.14 & 6.16 \\
\hline $\mathrm{K}_{2} \mathrm{O}$ & 0.08 & 16.10 & 0.20 & 15.27 & 15.89 & 0.14 & 0.11 \\
\hline $\mathrm{BaO}$ & 0.00 & 0.53 & 0.02 & 0.37 & 0.18 & 0.00 & 0.00 \\
\hline$\underline{\mathrm{SrO}}$ & 0.21 & 0.08 & 0.03 & 0.08 & 0.08 & 0.06 & 0.14 \\
\hline Total & 100.23 & 99.41 & 100.65 & 99.57 & 98.15 & 98.25 & 99.14 \\
\hline $\mathrm{Si}$ & 2.992 & 3.007 & 2.849 & 2.974 & 3.001 & 2.471 & 2.570 \\
\hline $\mathrm{A} 1$ & 1.001 & 0.989 & 1.134 & 1.005 & 0.993 & 1.516 & 1.422 \\
\hline $\mathrm{Fe}^{3+}$ & 0.000 & 0.000 & 0.005 & 0.006 & 0.001 & 0.002 & 0.001 \\
\hline T-site & 3.992 & 3.996 & 3.988 & 3.985 & 3.995 & 3.988 & 3.993 \\
\hline $\mathrm{K}$ & 0.005 & 0.952 & 0.011 & 0.898 & 0.953 & 0.008 & 0.006 \\
\hline $\mathrm{Na}$ & 0.953 & 0.024 & 0.873 & 0.063 & 0.044 & 0.458 & 0.540 \\
\hline $\mathrm{Ca}$ & 0.032 & 0.003 & 0.135 & 0.001 & 0.000 & 0.546 & 0.447 \\
\hline $\mathrm{Ba}$ & 0.000 & 0.010 & 0.000 & 0.007 & 0.003 & 0.000 & 0.000 \\
\hline $\mathrm{Sr}$ & 0.005 & 0.002 & 0.001 & 0.002 & 0.002 & 0.002 & 0.004 \\
\hline O-site & 0.994 & 0.991 & 1.019 & 0.972 & 1.003 & 1.014 & 0.997 \\
\hline $\mathrm{K}+\mathrm{Na}+\mathrm{Ca}$ & 0.989 & 0.979 & 1.018 & 0.963 & 0.997 & 1.012 & 0.993 \\
\hline An & 3.2 & 0.3 & 13.2 & 0.1 & 0.0 & 53.9 & 45.0 \\
\hline $\mathrm{Ab}$ & 96.3 & 2.4 & 85.7 & 6.6 & 4.4 & 45.3 & 54.4 \\
\hline Or & 0.5 & 97.3 & 1.1 & 93.3 & 95.6 & 0.8 & 0.6 \\
\hline
\end{tabular}

(calc-silicate rock - D031, schist - D107 and granodiorite - H056) 
Tab. 3 Representative chemical compositions of amphibole (granodiorite) and pyroxene (calc-silicate rock)

\begin{tabular}{|c|c|c|c|c|c|c|c|c|}
\hline Sample & H056/Amp & H056/Amp & H056/Amp & H056/Amp & $\mathrm{D} 031 / \mathrm{Px}$ & $\mathrm{D} 031 / \mathrm{Px}$ & $\mathrm{D} 031 / \mathrm{Px}$ & $\mathrm{D} 031 / \mathrm{Px}$ \\
\hline $\mathrm{SiO}_{2}$ & 48.67 & 48.86 & 48.24 & 49.10 & 52.05 & 52.04 & 50.78 & 51.41 \\
\hline $\mathrm{TiO}_{2}$ & 1.30 & 1.14 & 1.38 & 1.37 & 0.00 & 0.03 & 0.03 & 0.03 \\
\hline $\mathrm{Al}_{2} \mathrm{O}_{3}$ & 5.59 & 4.86 & 5.70 & 5.30 & 0.38 & 0.29 & 0.18 & 0.35 \\
\hline $\mathrm{Cr}_{2} \mathrm{O}_{3}$ & 0.15 & 0.09 & 0.08 & 0.09 & 0.02 & 0.00 & 0.01 & 0.00 \\
\hline $\mathrm{Fe}_{2} \mathrm{O}_{3}^{\text {calc }}$ & 3.48 & 4.82 & 2.90 & 4.55 & 0.47 & 1.38 & 1.75 & 1.21 \\
\hline $\mathrm{MnO}$ & 0.44 & 0.76 & 0.44 & 0.55 & 0.08 & 0.03 & 0.07 & 0.09 \\
\hline $\mathrm{MgO}$ & 11.96 & 11.16 & 11.56 & 11.91 & 9.07 & 10.37 & 7.26 & 8.53 \\
\hline $\mathrm{CaO}$ & 11.41 & 11.27 & 11.58 & 11.31 & 24.99 & 24.96 & 24.88 & 24.85 \\
\hline $\mathrm{Na}_{2} \mathrm{O}$ & 1.06 & 0.78 & 1.09 & 0.95 & 0.06 & 0.12 & 0.06 & 0.10 \\
\hline $\mathrm{K}_{2} \mathrm{O}$ & 0.47 & 0.38 & 0.50 & 0.43 & 0.01 & 0.00 & 0.00 & 0.01 \\
\hline $\mathrm{Cl}$ & 0.08 & 0.08 & 0.12 & 0.08 & - & - & - & - \\
\hline $\mathrm{F}$ & 0.15 & 0.07 & 0.11 & 0.14 & - & - & - & - \\
\hline $\mathrm{O}=\mathrm{F}+\mathrm{Cl}$ & -0.08 & -0.05 & -0.07 & -0.08 & - & - & - & - \\
\hline Total & 99.57 & 99.62 & 99.70 & 100.23 & 100.80 & 100.42 & 100.63 & 100.49 \\
\hline $\mathrm{Si}$ & 7.196 & 7.250 & 7.160 & 7.210 & 1.987 & 1.977 & 1.971 & 1.977 \\
\hline${ }^{\mathrm{IV}} \mathrm{Al}$ & 0.804 & 0.750 & 0.840 & 0.790 & 0.013 & 0.013 & 0.008 & 0.016 \\
\hline$\Sigma \mathrm{T}$ & 8.000 & 8.000 & 8.000 & 8.000 & 2.000 & 1.990 & 1.980 & 1.993 \\
\hline${ }^{\mathrm{V}} \mathrm{Al}$ & 0.171 & 0.100 & 0.158 & 0.127 & 0.004 & 0.000 & 0.000 & 0.000 \\
\hline $\mathrm{Ti}$ & 0.144 & 0.127 & 0.154 & 0.151 & 0.000 & 0.001 & 0.001 & 0.001 \\
\hline $\mathrm{Fe}^{3+}$ & 0.387 & 0.538 & 0.324 & 0.503 & 0.014 & 0.039 & 0.051 & 0.035 \\
\hline $\mathrm{Cr}$ & 0.017 & 0.010 & 0.010 & 0.011 & 0.001 & 0.000 & 0.000 & 0.000 \\
\hline $\mathrm{Mg}$ & 2.636 & 2.469 & 2.558 & 2.607 & 0.516 & 0.587 & 0.420 & 0.489 \\
\hline $\mathrm{Mn}$ & 0.056 & 0.095 & 0.055 & 0.068 & 0.002 & 0.001 & 0.002 & 0.003 \\
\hline $\mathrm{Ca}$ & 1.807 & 1.791 & 1.841 & 1.779 & 1.022 & 1.016 & 1.035 & 1.024 \\
\hline $\mathrm{Na}$ & 0.305 & 0.224 & 0.315 & 0.271 & 0.005 & 0.009 & 0.004 & 0.007 \\
\hline $\mathrm{K}$ & 0.089 & 0.072 & 0.095 & 0.080 & 0.000 & 0.000 & 0.000 & 0.000 \\
\hline $\mathrm{Cl}$ & 0.021 & 0.020 & 0.030 & 0.020 & - & - & - & - \\
\hline $\mathrm{F}$ & 0.068 & 0.031 & 0.053 & 0.063 & - & - & - & - \\
\hline$\Sigma \mathrm{CAT}$. & 15.269 & 15.118 & 15.303 & 15.193 & 4.000 & 4.000 & 4.000 & 4.000 \\
\hline
\end{tabular}

located at the termination of the zone affected by contact metamorphism around the small satellite massif of the Dipilto Batholith. Chlorite porphyroblasts (Fig. 2d), up to $0.7 \mathrm{~mm}$ across, are arranged parallel or subparallel to the axial planes of crenulation folds bending $\mathrm{S}_{1}$ which is defined by the mineral assemblage actinolite, epidote, feldspar, hematite and chlorite. The foliation $\mathrm{S}_{1}$ originated during the earliest regional metamorphism, which affected these rocks. Chlorite porphyroblasts are related to the intrusion of granodiorite.

\subsection{Metapelites, metapsammites and metavolcanites in the contact aureole}

Metapelitic horizons (Fig. 2c) are characterized by the assemblage andalusite, cordierite, biotite, quartz, pla- gioclase, K-feldspar, graphite and muscovite. Accessory minerals are ilmenite, tourmaline, zircon, monazite and rare pyrite. Cordierite $\left(\mathrm{X}_{\mathrm{Fe}}=0.56-0.57\right)$ occurs as ovoid porphyroblasts (Fig. 2e) with diffuse margins that overgrew the regional foliation. Inclusions of quartz, ilmenite, biotite, graphite and muscovite are abundant, whereas chlorite is rare. Andalusite often forms large chiastolitic prismatic grains (Fig. 2e) up to $12 \mathrm{~mm}$ in length, locally with small inclusions of quartz and biotite. The matrix of the metapelitic rock is composed of a fine-grained (0.01$0.03 \mathrm{~mm}$ ) granoblastic mosaic of quartz, plagioclase and $\mathrm{K}$-feldspar grains accompanied by small flakes of micas and graphite. Small subhedral grains of plagioclase (Tab. 2) are chemically homogenous $\left(\mathrm{An}_{13}\right)$. K-feldspar $\left(\mathrm{Ab}_{7}\right)$ is a minor phase. Biotite can be classified as annite $\left(\left(\mathrm{Fe} /(\mathrm{Mg}+\mathrm{Fe})=0.63-0.69,{ }^{\mathrm{IV}} \mathrm{Al}=2.68-2.91 \mathrm{apfu}\right)\right.$. It 
is in general more abundant than muscovite. Small prismatic crystals of dravite-rich tourmaline $(\mathrm{Fe} /(\mathrm{Fe}+\mathrm{Mg})$ $=0.44-0.50, \mathrm{Na}=0.46-0.62 \mathrm{apfu}, \mathrm{F}=0.00-0.01 \mathrm{apfu})$ were locally observed.

Most of the studied samples are affected by retrograde alteration. Cordierite is often partially or completely altered to fine-grained chlorite and muscovite. Pseudomorphs after andalusite porphyroblasts contain finegrained muscovite (Fig. 2f). Biotite is partly replaced by chlorite.

The metapsammites (Fig. 2c) are medium-grained rocks $(0.5-1.2 \mathrm{~mm})$ with granoblastic texture. The main constituents are subhedral plagioclase, anhedral quartz and minor K-feldspar and biotite. The modal compositions of the metapsammites (quartz 48-75, plagioclase 22-50, K-feldspar 1-5 vol. \%) suggest that the rocks originated from sandstone and arkose. Quartz may form sub-rounded grains, which display recrystallization to sub-grains. Porphyroblasts of albite up to $2 \mathrm{~mm}$ long occur rarely. Larger grains occasionally show polysynthetic twinning.
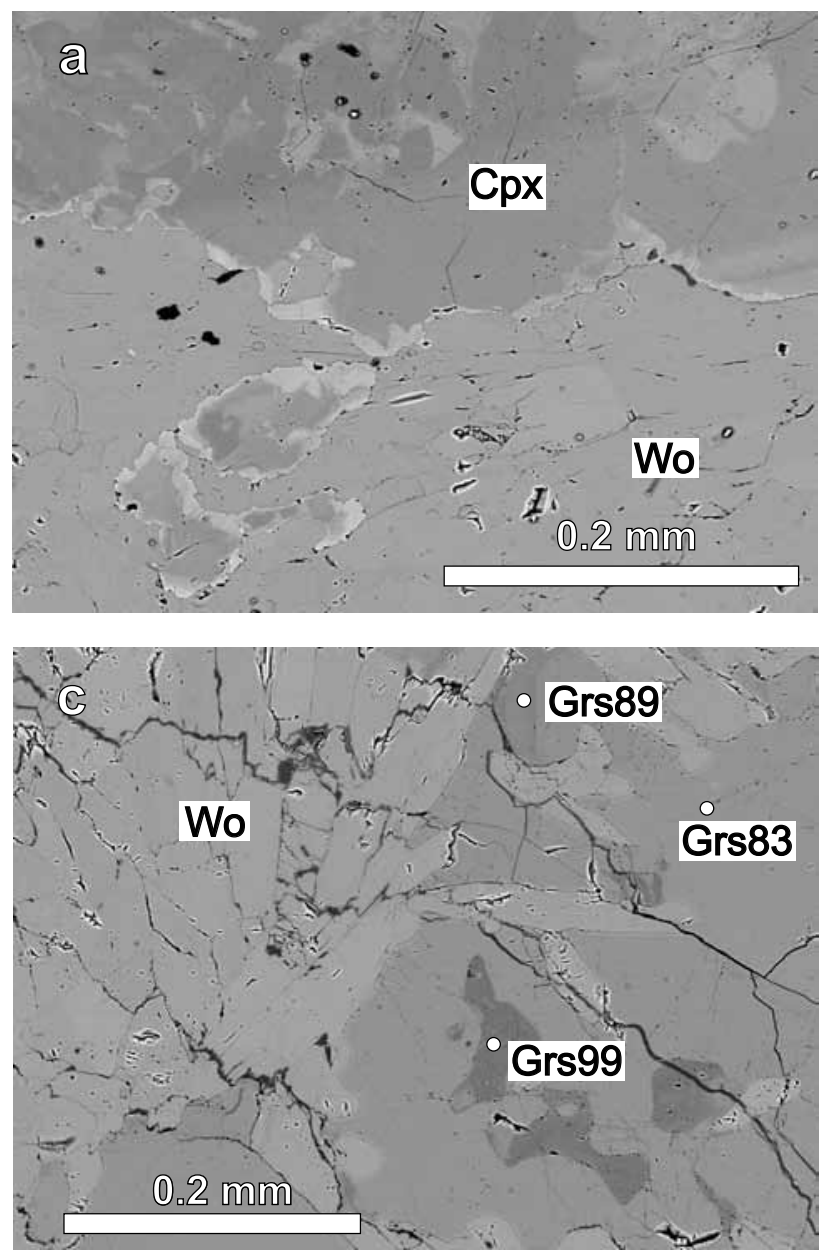

Staurolite porphyroblasts up to $2 \mathrm{~mm}$ in size are rare. Up to several-meter-thick layers of polymictic metaconglomerate occur occasionally. They are matrix-supported, with clast diameters of $1-10 \mathrm{~cm}$. The clasts are well rounded, highly elongated and composed mainly of metasediments, less frequently of metavolcanite, quartzite and vein quartz.

Basic metavolcanites (amphibolite to greenschist) form several-meter-thick bodies or layers. Amphibolite is typical of the contact aureole near the town of Jalapa. Fine- to medium-grained amphibolite is predominantly dark greenish and commonly moderately to strongly foliated. It consists of subhedral plagioclase, subhedral to anhedral hornblende and actinolite, subordinate subhedral biotite, opaque minerals and interstitial quartz. Titanite and epidote are common accessory minerals.

\subsection{Calc-silicate rocks in the contact aureole}

Calc-silicate rocks form small lenses (up to $20 \mathrm{~m}$ long) in association with metapelitic and metapsammitic li-
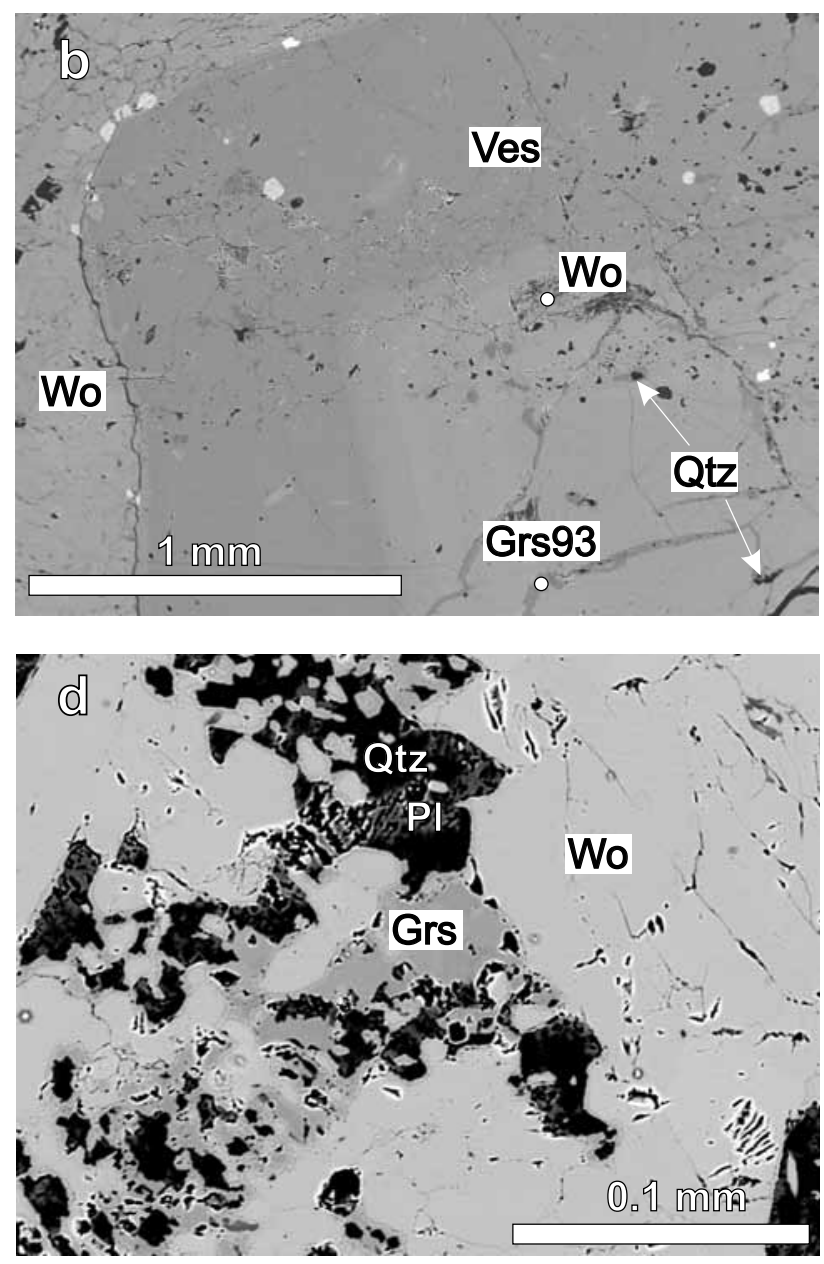

Fig. 4 Typical textures of calc-silicate rocks (sample D31) from the Agua Fría Formation (in BSE): a - Irregular, patchily-zoned clinopyroxene grains with an iron-rich rim; b - Vesuvianite porphyroblast cut by grossular veinlets (Grs93 = grossular component (mol. \%) content in garnet); $\mathbf{c}$-Anhedral grains of grossular with wollastonite inclusions; $\mathbf{d}$-Grossular-quartz intergrowths at the contact between wollastonite and plagioclase. 
thologies. These calc-silicate bodies are arranged within an about $4 \mathrm{~km}$ long metamorphic rock bed, situated in the vicinity of the village of Intelí, $10 \mathrm{~km} \mathrm{SW}$ of Jalapa (Tab. 1). The calc-silicate rocks are medium-grained, pale-green, grey or white. A typical mineral assemblage is wollastonite + diopside \pm vesuvianite \pm grossular \pm calcite \pm plagioclase \pm K-feldspar \pm quartz (Fig. 4). The rocks are banded and there is a considerable variation in the mineralogy of the individual bands. The outcrops commonly exhibit folded, white to greenish wollastonite-rich or diopside-rich layers that alternate with grey quartz-rich ones (several $\mathrm{mm}$ to $\mathrm{cm}$ thick). Wollastonite occurs as nearly monomineral layers (containing $>90 \mathrm{vol}$. \% wollastonite), accumulations with equigranular nematoblastic texture or isolated small needles enclosed in quartz or feldspar. Wollastonite can host small inclusions of quartz, plagioclase and calcite. Clinopyroxene porphyroblasts are subhedral and sometimes contain small inclusions of wollastonite. Clinopyroxene chemical composition (Tab. 3) is essentially close to the diopside/hedenbergite bound- ary $\left(\mathrm{X}_{\mathrm{Fe}}=40-57\right)$. Clinopyroxene grains are irregularly patchily-zoned with an iron-rich rim (Fig. 4a). Younger Fe-rich vesuvianite $\left(\mathrm{X}_{\mathrm{Fe}}=57-62, \mathrm{~F}=2.5-3.2 \mathrm{apfu}\right)$ occurs as euhedral, oscillatory zoned (Tab. 4), up to $10 \mathrm{~mm}$ long porphyroblasts (Fig. 4b), irregularly distributed in rocks or arranged in small veins. Subhedral vesuvianite grains up to $1 \mathrm{~mm}$ in size occurring in the matrix have slightly different chemical composition $\left(\mathrm{X}_{\mathrm{Fe}}=51-57, \mathrm{~F}\right.$ $=2.5-3.2 \mathrm{apfu}$ ). Vesuvianite contains abundant inclusions of garnet, diopside, wollastonite, apatite and calcite. Grossular (Tab. 4) forms euhedral to anhedral grains ( $\mathrm{Grs}_{83-99}$, $\left.\mathrm{Adr}_{1-16}\right)$ in the matrix. These grains are in general chemically homogeneous but may contain an iron-free core (Fig. 4c) of irregular shape. Younger grossular forms fine-grained intergrowths with quartz at the contact with plagioclase and wollastonite (Fig. 4d). Youngest grossular \pm quartz \pm calcite veinlets $\left(\mathrm{Grs}_{93}, \mathrm{Adr}_{7}\right)$ often crosscut vesuvianite porphyroblasts (Fig. 4b). Fine-grained subhedral plagioclase $\left(\mathrm{An}_{3}\right)$ and $\mathrm{K}$-feldspar $\left(\mathrm{Ab}_{2}\right)$ have a uniform chemical composition (Tab. 2) and often form symplec-

Tab. 4 Representative chemical compositions of vesuvianite (Ves) and garnet (Grt) (calc-silicate rock)

\begin{tabular}{|c|c|c|c|c|c|c|c|c|}
\hline Sample & D031/VesI & D031/VesII & D031/VesII & D031/VesII & D031/GrtI & D031/GrtII & D031/GrtII & D031/GrtIII \\
\hline $\mathrm{SiO}_{2}$ & 36.73 & 36.01 & 36.53 & 36.23 & 39.33 & 38.52 & 38.61 & 38.67 \\
\hline $\mathrm{TiO}_{2}$ & 1.02 & 1.64 & 0.06 & 2.18 & 0.00 & 0.05 & 0.02 & 0.09 \\
\hline $\mathrm{Al}_{2} \mathrm{O}_{3}$ & 17.72 & 16.35 & 17.23 & 16.33 & 22.61 & 19.66 & 19.90 & 21.35 \\
\hline $\mathrm{Cr}_{2} \mathrm{O}_{3}$ & - & - & - & - & 0.00 & 0.02 & 0.00 & 0.02 \\
\hline $\mathrm{Fe}_{2} \mathrm{O}_{3}$ & - & - & - & - & 0.30 & 5.58 & 4.46 & 2.50 \\
\hline $\mathrm{FeO}$ & 3.46 & 3.92 & 4.15 & 4.19 & 0.00 & 0.31 & 0.00 & 0.00 \\
\hline $\mathrm{MnO}$ & 0.00 & 0.01 & 0.02 & 0.00 & 0.01 & 0.06 & 0.00 & 0.01 \\
\hline $\mathrm{MgO}$ & 1.45 & 1.51 & 1.75 & 1.58 & 0.02 & 0.12 & 0.00 & 0.01 \\
\hline $\mathrm{Na}_{2} \mathrm{O}$ & 0.07 & 0.06 & 0.03 & 0.12 & 0.02 & 0.00 & 0.01 & 0.00 \\
\hline $\mathrm{CaO}$ & 36.26 & 36.27 & 36.18 & 35.78 & 38.73 & 35.62 & 37.37 & 36.76 \\
\hline $\mathrm{F}$ & 1.86 & 1.98 & 1.91 & 1.58 & 0.10 & 0.14 & 0.00 & 0.09 \\
\hline $\mathrm{Cl}$ & 0.06 & 0.06 & 0.10 & 0.07 & - & - & - & - \\
\hline Total & 98.62 & 97.79 & 97.95 & 98.05 & 101.12 & 100.09 & 100.39 & 99.49 \\
\hline $\mathrm{Si}$ & 18.326 & 18.207 & 18.418 & 18.335 & 2.917 & 2.943 & 2.927 & 2.938 \\
\hline $\mathrm{Ti}$ & 0.381 & 0.625 & 0.024 & 0.831 & 0.000 & 0.003 & 0.001 & 0.005 \\
\hline $\mathrm{Al}$ & 10.418 & 9.742 & 10.241 & 9.744 & 1.976 & 1.769 & 1.778 & 1.912 \\
\hline $\mathrm{Cr}$ & - & - & - & - & 0.000 & 0.001 & 0.000 & 0.001 \\
\hline $\mathrm{Fe}^{3+}$ & - & - & - & - & 0.017 & 0.321 & 0.255 & 0.143 \\
\hline $\mathrm{Fe}^{2+}$ & 1.442 & 1.657 & 1.749 & 1.773 & - & 0.020 & 0.000 & 0.000 \\
\hline $\mathrm{Mn}$ & 0.000 & 0.002 & 0.009 & 0.000 & - & 0.004 & 0.000 & 0.001 \\
\hline $\mathrm{Mg}$ & 1.077 & 1.138 & 1.317 & 1.190 & 0.002 & 0.014 & 0.000 & 0.001 \\
\hline $\mathrm{Ca}$ & 19.385 & 19.648 & 19.545 & 19.402 & 3.078 & 2.915 & 3.036 & 2.993 \\
\hline $\mathrm{Na}$ & 0.067 & 0.054 & 0.024 & 0.115 & 0.002 & 0.000 & 0.002 & 0.000 \\
\hline $\mathrm{F}$ & 2.939 & 3.165 & 3.039 & 2.532 & 0.024 & 0.035 & 0.000 & 0.021 \\
\hline $\mathrm{Cl}$ & 0.049 & 0.051 & 0.082 & 0.059 & - & - & - & - \\
\hline$\Sigma$ CAT. & 54.085 & 54.288 & 54.448 & 53.983 & 8.017 & 8.025 & 7.999 & 8.014 \\
\hline $\mathrm{O}$ & 78 & 78 & 78 & 78 & 12 & 12 & 12 & 12 \\
\hline
\end{tabular}

GrtI - garnet core, GrtII - garnet rim, GrtIII - garnet from veins in vesuvianite, Ves I - vesuvianite in matrix, Ves II - vesuvianite porphyroblast 
titic intergrowths with wollastonite. Subhedral calcite is chemically very pure ( $\mathrm{FeO}$ up to 0.27 wt. $\%, \mathrm{MnO}$ and $\mathrm{MgO}$ up to 0.01 wt. \%). Titanite, apatite, zircon, and pyrrhotite are accessory phases. Calc-silicate rock is crosscut by younger quartz veins, up to several mm thick.

\section{Fluid inclusions}

Fluid inclusions (FI) can be used for estimation of the composition of the fluid trapped during crystallization of the given mineral. Vesuvianite from the studied younger porphyroblasts in calc-silicate rocks contains two types of fluid inclusions:

1) Primary FI occur as solitary or in small threedimensional clusters. The primary inclusions are associated with the occurrence of solid inclusions formed by wollastonite needles and isometric opaque phases. Fluid inclusions are often well-developed and relatively large (up to $36 \mu \mathrm{m}$ ); the shapes are isometric, spherical, mostly without any tips. At room temperature, a two-phase composition (aqueous solution + bubble) with a limited range of liquid-vapour ratios ( $20-30$ vol. \% of non-aqueous phase) was observed in all FI. Occasionally, unidentified solid phases can also be present (mainly crystallized on the walls of inclusions), but they must be considered to be accidentally trapped solids, as they do not exhibit any changes during microthermometry.

Primary fluid inclusions freeze at temperatures of -31 to $-45^{\circ} \mathrm{C}$. Sometimes, a double-freezing behaviour is observed, which is consistent with the presence of a clathrate-forming gas. During subsequent heating, the rarely observed first melting occurred at a temperature $\mathrm{T}_{e}$ of $-38^{\circ} \mathrm{C}$, which is indicative of aqueous solutions containing magnesium chloride and/or iron chloride, both possibly combined with sodium chloride (Shepherd et al. 1985). During further heating, no salt hydrate melting was observed. The last ice melted at $\mathrm{T}_{\text {m-ice }}$ between -1.2 and $-3.2{ }^{\circ} \mathrm{C}$ (Fig. 5a). The last phase to melt is clathrate (Fig. 5b). The $\mathrm{T}_{\mathrm{m}-\mathrm{cla}}$ temperatures vary between +9.5 and $+21.2^{\circ} \mathrm{C}$. Because of the low salinity of the aqueous fluid, the isotropic crystals of clathrate are essentially invisible in these inclusions, and final clathrate dissociation could be identified only if careful cycling was used. The total homogenization of the inclusion content occurred at temperatures between 225 and $355^{\circ} \mathrm{C}$ (Fig. $5 \mathrm{c}$ ); however, starting at about $270^{\circ} \mathrm{C}$, part of the inclusions decrepitated prior to reaching the homogenization point.

2) Secondary FI are situated within healed microfractures. They are flat, often with a very tiny boundary and appear to be two-phase (liquid + vapour) at room temperature but, in comparison with primary FI, exhibit a wider variability of liquid-vapour ratios $(\sim 5-30$ vol. $\%$ of vapour).
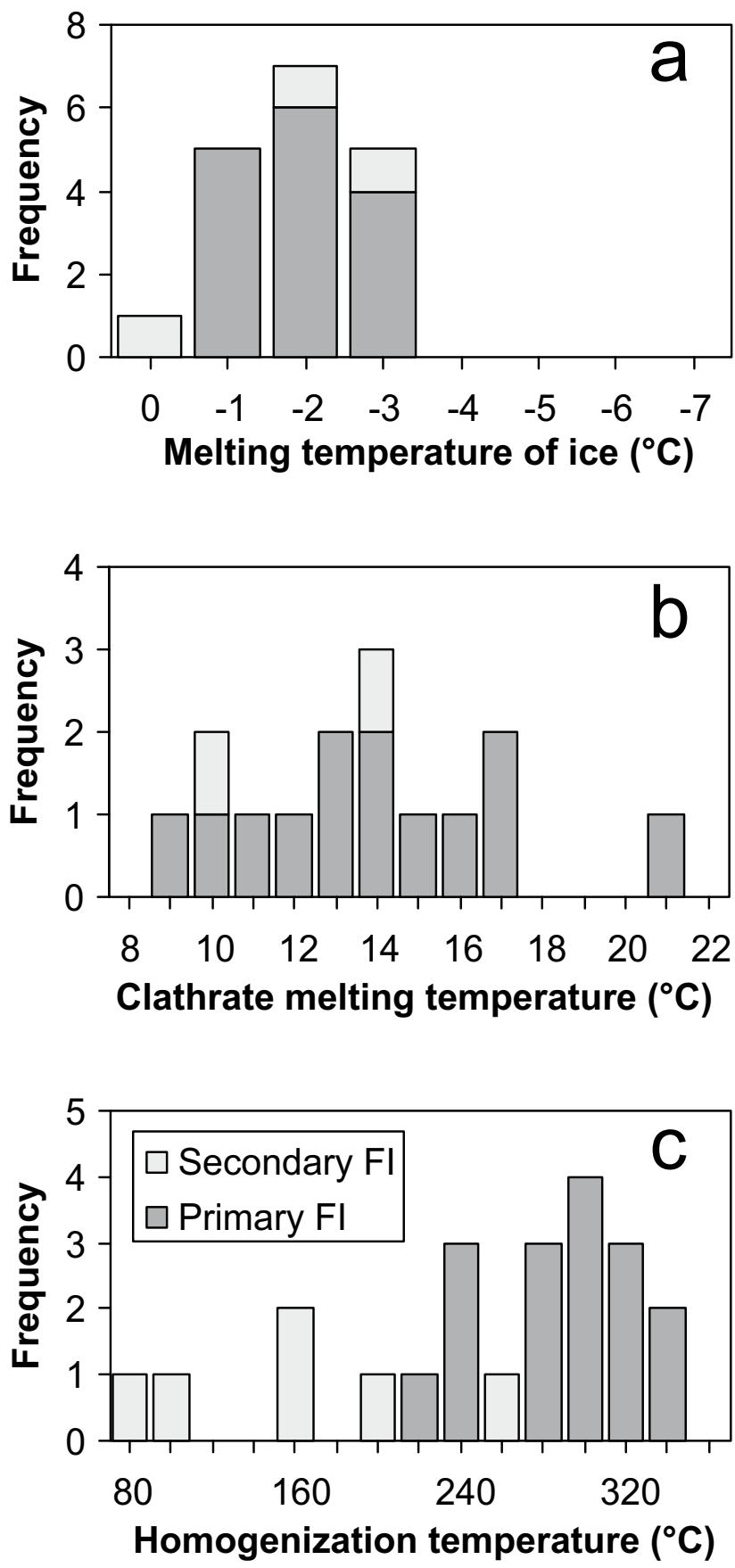

Fig. 5 Results of fluid inclusion microthermometry: $\mathbf{a}$ - histogram of melting temperatures of the last ice; $\mathbf{b}$ - histogram of clathrate melting temperatures; $\mathbf{c}$ - histogram of homogenization temperatures.

Microthermometric measurements revealed the presence of two subtypes of FI. Some of the trail-hosted inclusions have similar parameters to the primary FI, whereas the rest differs in the absence of clathrateforming gas. This second group is characterized by lower homogenization temperatures $\left(88-272{ }^{\circ} \mathrm{C}\right)$ and greater spread of the ice melting temperatures $(-3.3$ to $\left.-0.3{ }^{\circ} \mathrm{C}\right)$. 


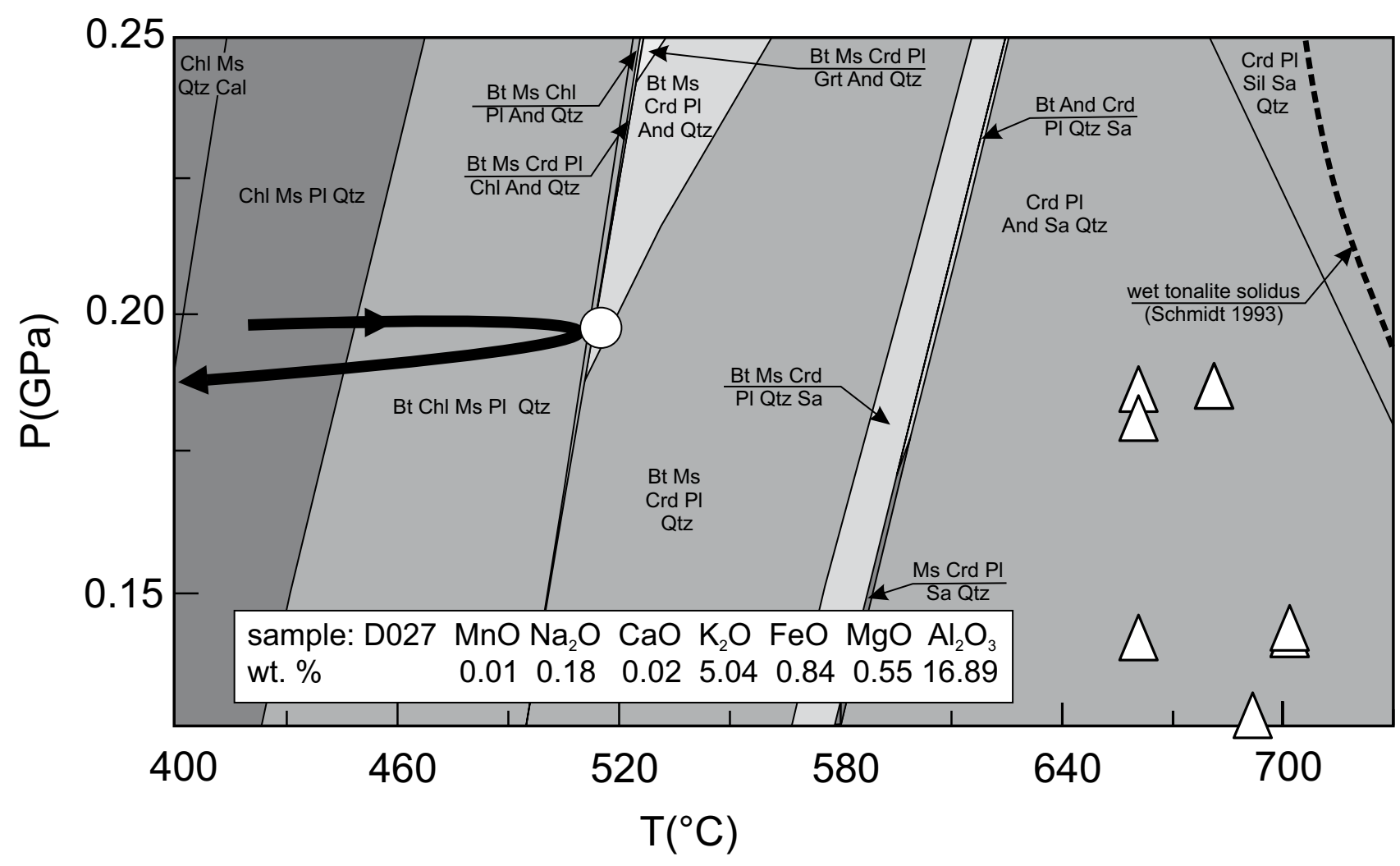

Fig. 6 P-T pseudosection for metapelite from the Dipilto Batholith contact aureole (sample D027, taken $c .100 \mathrm{~m}$ of the contact) calculated in the MnNCKFMASH system using the PERPLEX software. The bulk-rock composition (in wt. \%) used for the calculation is indicated at the bottom. The light grey, medium grey and dark grey fields are tri-, quadri- and quintvariant fields, respectively. The dark arrow shows the assumed P-T path for sample D027 and the white circle corresponds to inferred peak conditions of metamorphism. The white triangles represent the temperature and pressure estimates from the hornblende-plagioclase thermometry (Holland and Blundy 1994) and hornblende barometer (Anderson and Smith 1995) from granodiorites.

\section{P-T conditions}

\subsection{Granodiorites and tonalites}

The temperature and pressure estimated from hornblende-plagioclase thermometry (Holland and Blundy 1994) and Al-in-hornblende barometer (Anderson and Smith 1995) were used to characterize the emplacement conditions of the amphibole-biotite granodiorites. Solidus temperature estimates using the magnesiohornblende $(\mathrm{Mg} /(\mathrm{Mg}+\mathrm{Fe})=0.55-0.58, \mathrm{Si}=7.13-7.30 \mathrm{apfu})$ and plagioclase $\left(\mathrm{An}_{27-31}\right)$ rim compositions yielded temperatures of $629-727{ }^{\circ} \mathrm{C}$ and pressure estimates of $c$. $0.1-0.2 \mathrm{GPa}$ (Fig. 6). The wide range calculated for the temperature conditions can be interpreted as a result of re-equilibration during cooling of the Dipilto Batholith. Obtained results are below, but relatively close, to the wet solidus of the tonalite melt (Schmidt 1993) and should indicate $\mathrm{P}-\mathrm{T}$ conditions characterizing the emplacement of amphibole-biotite granodiorites.

\subsection{Metapelites}

The low-pressure $\mathrm{Crd}+\mathrm{And}+\mathrm{Ms}+\mathrm{Bt}$ and $\mathrm{Crd}+\mathrm{And}+$ $\mathrm{Bt}+\mathrm{Kfs} \pm \mathrm{Ms}$ assemblages are interpreted as a prograde sequence of the MnNCKFMASH model reactions consuming muscovite and generating cordierite, andalusite and K-feldspar. Cordierite porphyroblasts contain inclusions of graphite, muscovite and chlorite, which indicate formation of cordierite by the reaction:

$$
\mathrm{Ms}+\mathrm{Chl}+\mathrm{Qtz}=\mathrm{Crd}+\mathrm{Bt}+\mathrm{H}_{2} \mathrm{O}
$$

Andalusite locally includes biotite grains from the matrix. These textures are consistent with prograde andalusite growth (Pattison et al. 2002):

$$
\mathrm{Ms}+\mathrm{Crd}=\mathrm{And}+\mathrm{Bt}+\mathrm{Qtz}+\mathrm{H}_{2} \mathrm{O}
$$

Appearance of K-feldspar in the internal part of the contact aureole indicates the reaction: 


$$
\mathrm{Ms}+\mathrm{Qtz}=\mathrm{And}+\mathrm{Kfs}+\mathrm{H}_{2} \mathrm{O}
$$

However, frequently coexisting K-feldspar and muscovite can be explained by the reaction:

$$
\mathrm{Ms}+\mathrm{Bt}+\mathrm{Qtz}=\mathrm{Crd}+\mathrm{Kfs}+\mathrm{H}_{2} \mathrm{O}
$$

or as a result of retrograde replacement of K-feldspar.

On the basis of petrographic observations, the metamorphic assemblage And $+\mathrm{Crd}+\mathrm{Ms}+\mathrm{Bt}$ is considered as primary for studied sample D027. The MnNCKFMASH petrogenetic grid in Fig. 6 shows that andalusite, together with muscovite, appears at a pressure of $0.2 \mathrm{GPa}$ and at low temperatures of $510-520^{\circ} \mathrm{C}$. The metamorphic assemblage $\mathrm{Crd}+\mathrm{Kfs}+\mathrm{Bt} \pm \mathrm{Ms} \pm$ And requires slightly higher temperature of $\sim 600^{\circ} \mathrm{C}$. Using the diagram of Connolly and Cesare (1993), the $\mathrm{X}_{\mathrm{H}_{2} \mathrm{O}}$ value for a pressure of $\sim 0.2 \mathrm{GPa}$ and temperature of $450-650^{\circ} \mathrm{C}$ ranges from 0.75 to 0.95 . According to the mineral assemblage of the studied sample D027, we consider that $\mathrm{X}_{\mathrm{H}_{2} \mathrm{O}}$ was equal to approximately 0.9 .

Andalusite in sample D027 is completely replaced by retrograde white mica. Intergrowths of muscovite and chlorite form pseudomorphs after cordierite. Primary biotite is partially replaced by chlorite. Retrograde minerals can be interpreted as a result of metamorphic reactions under high water activity during decreasing temperature. These reactions reflect cooling along the retrograde $\mathrm{P}-\mathrm{T}$ path (Fig. 6).

\subsection{Calc-silicate rocks}

Vesuvianite-bearing calc-silicate rocks (sample D031) consist of the peak mineral assemblage (Fig. 7) Wo + Di $+\mathrm{Grs}+\mathrm{Ves}+\mathrm{Qtz}+\mathrm{Ab}+\mathrm{Kfs}+\mathrm{Cal}$ (preserved only as abundant inclusions in other minerals). Younger vesuvianite also forms post-peak veins and porphyroblasts. Experimental phase-equilibria studies of vesuvianite suggest that this mineral is stable only under conditions with high $\mathrm{H}_{2} \mathrm{O}$ activity (e.g. Hochella et al. 1982). Water-rich fluids are normally exsolved during crystallization of plutonic rocks. The occurrence of vesuvianite porphyroblasts and veins is restricted to water-rich conditions with $\mathrm{X}_{\mathrm{CO}_{2}}$ below 0.2 in a $\mathrm{CO}_{2}-\mathrm{H}_{2} \mathrm{O}$ fluid system (Buick and Holland 1991). The grossular-rich garnet core $\left(\mathrm{Grs}_{99}\right)$ without inclusions was probably produced during prograde contact metamorphism as a result of the reaction (Fig. 7):

$$
2 \mathrm{Cal}+\mathrm{An}+\mathrm{Qtz}\left(\text { or } \mathrm{SiO}_{2} \text { in fluid }\right)=\mathrm{Grs}+2 \mathrm{CO}_{2}
$$

The prevailing mineral is wollastonite, rarely with calcite inclusions. This corresponds to the reaction:

$$
\mathrm{Cal}+\mathrm{Qtz}\left(\text { or } \mathrm{SiO}_{2} \text { in fluid }\right)=\mathrm{Wo}+\mathrm{CO}_{2}
$$

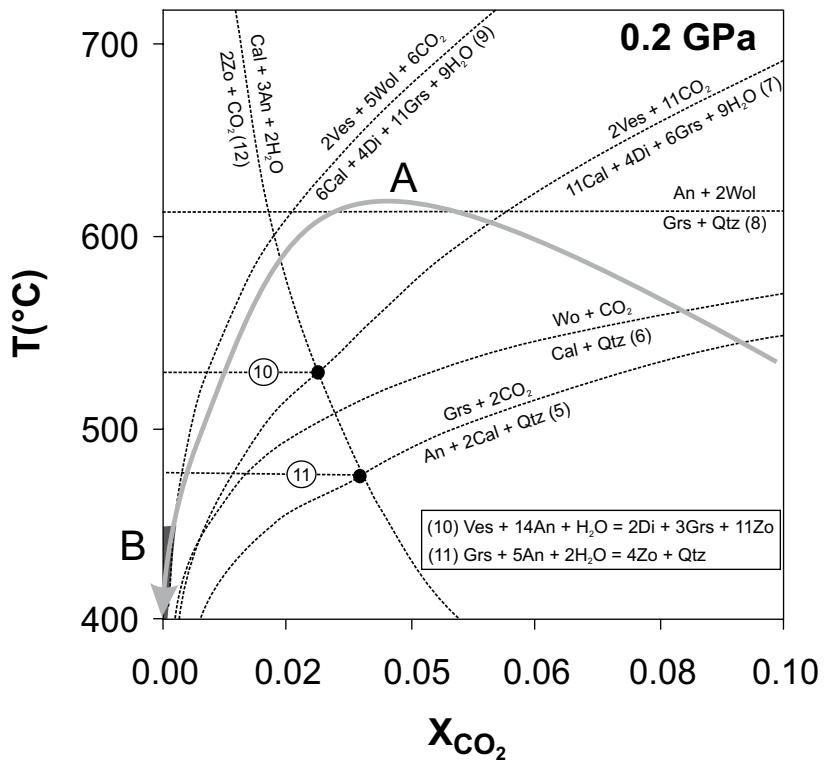

Fig. 7 The isobaric $\mathrm{T}-\mathrm{X}_{\mathrm{CO}}$ plot of metamorphic reactions in the calc-silicate rock (sample D31) constructed for core composition of garnet, clinopyroxene and calcite. The position of the reactions was calculated using the THERMOCALC 3.3 program $(\mathrm{A}=$ peak conditions, $\mathrm{B}=\mathrm{T}-$ $\mathrm{X}_{\mathrm{CO}_{2}}$ conditions calculated from fluid inclusions trapped in vesuvianite.

The presence of calcite and diopside inclusions in the vesuvianite from the matrix indicates the reaction:

$11 \mathrm{Cal}+4 \mathrm{Di}+5 \mathrm{An}+6 \mathrm{Grs}+9 \mathrm{H}_{2} \mathrm{O}=2 \mathrm{Ves}+11 \mathrm{CO}_{2}(7)$.

The garnet rims contain abundant inclusions of wollastonite, which suggests a fluid-absent reaction:

$$
2 \mathrm{Wo}+\mathrm{An}=\mathrm{Grs}+\mathrm{Qtz}
$$

Garnet-quartz symplectites around wollastonite (Fig. 4 d) grains at the contact with feldspars are a result of the same reaction. For a pressure of about $0.2 \mathrm{GPa}$, the peak temperature conditions are estimated to be above $610^{\circ} \mathrm{C}$.

The inclusions of wollastonite, calcite and diopside in younger vesuvianite porphyroblasts indicate that it formed via the decarbonation reaction:

$6 \mathrm{Cal}+4 \mathrm{Di}+11 \mathrm{Grs}+9 \mathrm{H}_{2} \mathrm{O}=2 \mathrm{Ves}+5 \mathrm{Wo}+6 \mathrm{CO}_{2}$

\section{Discussion}

\subsection{Interpretation of fluid inclusions from vesuvianite}

The presence of clathrates suggests that clathrate-forming gas $\left(\mathrm{CO}_{2}, \mathrm{~N}_{2}, \mathrm{CH}_{4}\right.$ or other hydrocarbons) occurs in the primary and part of the secondary fluid inclusions. Car- 
bon dioxide as a predominant constituent is unlikely since the clathrate melting temperatures are mostly significantly higher than the upper stability limits of $\mathrm{CO}_{2}$-clathrate $\left(+10.0^{\circ} \mathrm{C}\right.$; Collins 1979). Although the nitrogen clathrate can exist up to temperatures of $c .+52.5^{\circ} \mathrm{C}$ (Dyadin et al. 2001), the obtained fluid inclusion data are incompatible with models incorporated in the ICE software (Bakker 2003). Hydrocarbons other than methane can also be omitted with respect to the high fluid temperatures well exceeding $\sim 180^{\circ} \mathrm{C}$, the upper temperature stability limit of higher hydrocarbons (Allen and Allen 1990). Methane thus remains the most relevant candidate for a predominant gas constituent of the primary FI. When the fluid composition is approximated by the $\mathrm{CH}_{4}-\mathrm{H}_{2} \mathrm{O}-\mathrm{NaCl}$ system, then the microthermometric data are compatible with 88.9-93.8 mol. \% water, 3.4-9.9 mol. \% methane and $1.2-2.8 \mathrm{~mol} . \% \mathrm{NaCl}$. The salinity of the aqueous solution ranges between 3.0 and 4.7 wt. $\% \mathrm{NaCl}$. The bulk molar volumes of the fluid are 22.97 to $24.68 \mathrm{~cm}^{3} / \mathrm{mol}$.

The reaction between graphite in the surrounding metapelites and aqueous fluids under reducing conditions $\left(2 \mathrm{C}+2 \mathrm{H}_{2} \mathrm{O}=\mathrm{CH}_{4}+\mathrm{CO}_{2}\right)$ can be suggested as the most probable mechanism for the formation of methanebearing inclusions (Roedder 1984; Crespo et al. 2004).

The limited variability in the phase composition of the primary FI indicates that they have been trapped from a homogeneous fluid phase. Under these conditions, the measured total homogenization temperatures are lower than the trapping temperatures. Determination of the real $\mathrm{P}-\mathrm{T}$ conditions is possible only using a combination of isochores and independent temperature and/or pressure estimates. The isochores calculated for primary inclusions and temperature range for crystallization of younger vesuvianite, under a pressure of about $0.2 \mathrm{GPa}$, are plotted in Fig. 8.

\subsection{Deformation and metamorphic phases}

Three discrete periods of metamorphism were distinguished in the metasedimentary rocks surrounding the Dipilto Batholith: (1) low-pressure and low-temperature regional metamorphism $\mathrm{M}_{1}$ and deformation $\mathrm{D}_{1}$ that overprinted primary sedimentary textures; (2) relatively lowpressure and high-temperature contact metamorphism $\mathrm{M}_{2}$, locally accompanied by deformation $\mathrm{D}_{2}$, (3) low-pressure and low-temperature retrograde metamorphism $\mathrm{M}_{3}$ with local development of ductile shear zones $\mathrm{D}_{3}$ (Fig. 8).

\subsubsection{Early deformation related to regional metamorphism $\left(\mathrm{M}_{1}, \mathrm{D}_{1}\right)$}

The earliest recognizable tectonic microstructures are visible in the outer zone of the contact aureole. The metapelite and metapsammite contain foliation $\mathrm{S}_{1}$ defined by the orientation of chlorite and muscovite flakes. The studied greenschist sample from the outcrop near San Juan del Río Coco exhibits older folded foliation $\left(\mathrm{S}_{1}\right)$ defined by the syn-tectonic mineral assemblage actinolite + albite + epidote \pm quartz \pm chlorite $\left(\mathrm{M}_{1}\right)$.

\subsubsection{Contact metamorphism $\left(\mathrm{M}_{2}, \mathrm{D}_{2}\right)$}

The Cretaceous Dipilto Batholith consists of amphibolebiotite tonalite to granodiorite with enclaves of amphibole gabbros to diorites. Granodiorite was emplaced at a pressure of c. $0.2 \mathrm{GPa}$, equivalent to a depth of c. $6 \mathrm{~km}$.

Metapelite is the most abundant rock type in the contact aureole and its thermal metamorphism is characterized by the development of cordierite, andalusite and muscovite $\left(c .500{ }^{\circ} \mathrm{C}\right)$ to cordierite, andalusite and $\mathrm{K}$-feldspar mineral assemblage $\left(650^{\circ} \mathrm{C}\right)$. The occurrence

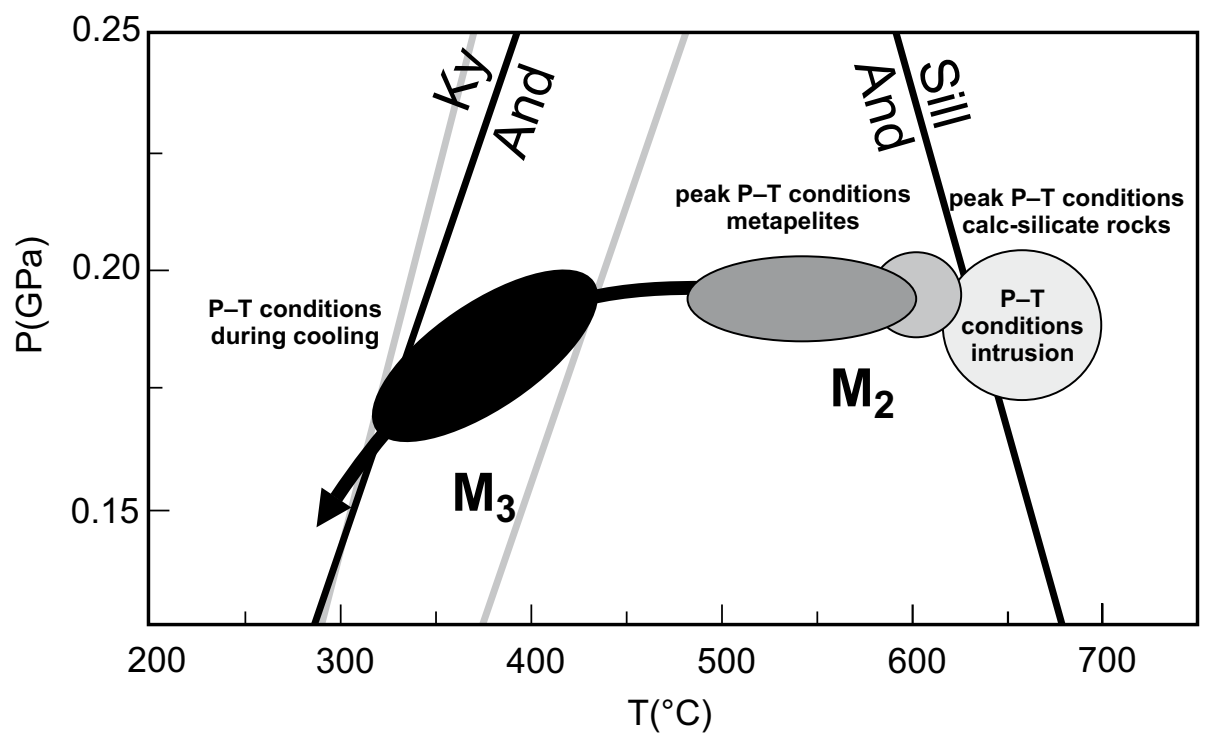

Fig. 8 Presumed $\mathrm{P}-\mathrm{T}$ metamorphic evolution of metapelites and calcsilicate rocks in the Dipilto Batholith contact aureole based on the mineral assemblages as well as compositions and density of fluid inclusions (the grey lines are isochores calculated for primary fluid inclusions). 
of andalusite and/or cordierite in metapelites is restricted by the whole-rock composition and the amount of graphite present (Pattison et al. 2002).

Possible cordierite-producing reactions for metapelites include $\mathrm{Ms}+\mathrm{Chl}+\mathrm{Qtz}=\mathrm{Crd}+\mathrm{Bt}+\mathrm{H}_{2} \mathrm{O}$ (1) in the external and $\mathrm{Ms}+\mathrm{Bt}+\mathrm{Qtz}=\mathrm{Crd}+\mathrm{Kfs}+\mathrm{H}_{2} \mathrm{O}$ (4) in the internal part of the contact aureole. Andalusite is considered to be a product of dehydration reactions that involve the breakdown of muscovite (reactions 2 and 3). Majority of andalusite and cordierite grew over pre-existing foliation $\mathrm{S}_{1}$ and forms post-tectonic poikiloblasts (Fig. 2e). On the other hand, metamorphic rocks with new foliation $\mathrm{S}_{2}$ (Fig. 2d) and syn-tectonic poikiloblasts of cordierite have been rarely found near the contact with granitoids. Inclusion trails within these poikiloblasts show gentle rotation. The emplacement of the Dipilto Batholith at shallow crustal levels was thus locally accompanied by a weak deformation of the metasediments $\left(\mathrm{D}_{2}\right)$.

Marbles and calc-silicate rocks form small boudins enclosed in metapelites near the contact with granitoids of the Dipilto Batholith. Carbonates and minor silicates (for example, An-rich plagioclase) in the calc-silicate boudins, affected by low-grade regional metamorphism, were exhausted as reactants for reactions $5-9$, producing successively diopside, grossular, wollastonite and vesuvianite. This mineral assemblage is a typical product of the rock interaction with water-rich fluids (Hochella et al. 1982; Gerdes and Valley 1994). Given their mineralogy and geological position, we assume that calc-silicate rocks were pervasively percolated by water-rich fluids generated during crystallization of the granitoids. A fluid source in the pluton itself is favoured because occurrences of wollastonite, grossular and vesuvianite are spatially related to the contact aureole. Moreover, the mineral assemblages of metapelites in the external part of the aureole reflect markedly lower $\mathrm{P}-\mathrm{T}$ conditions than the peak conditions estimated for calc-silicate rocks. During peak $\mathrm{P}-\mathrm{T}$ conditions at $\sim 610{ }^{\circ} \mathrm{C}$ (for pressure of 0.2 $\mathrm{GPa}$ ), the mineral assemblage $\mathrm{Wo}+\mathrm{Di}+\mathrm{Grs}+\mathrm{Qtz}+\mathrm{Ves}$ $+\mathrm{Pl}+\mathrm{Kfs}+\mathrm{Cal}$ was stable. Garnet was partially replaced by wollastonite and anorthite. Minor An-rich plagioclase was exhausted during previous retrograde metamorphic reaction 8. Decomposition of alkali feldspar to K-feldspar and albite intergrowths is consistent with retrogression to a lower temperature.

\subsubsection{Retrograde metamorphism and young deformation $\left(\mathrm{M}_{3}, \mathrm{D}_{3}\right)$}

The microstructures suggest that magmatic fabric of granitoids was overprinted by younger subsolidus deformation during the early stages of the Dipilto Batholith cooling (Fig. 3). Ductile shear zones developed mainly in porphyritic biotite granodiorite with cordierite are several meters thick. Foliation $\left(\mathrm{S}_{3}\right)$ is marked by the preferred orientation of biotite, alkali feldspar phenocrysts and/ or elongation of muscovite-chlorite pseudomorphs after cordierite (Fig. 2a). Deformed rocks pass progressively into granodiorite with magmatic fabric.

Most samples from the contact aureole contain later chlorite in the metapelitic matrix, which is related to the retrograde event $\left(\mathrm{M}_{3}\right)$. In many studied samples, fine intergrowths of muscovite and chlorite form pseudomorphs after cordierite. Andalusite is replaced by randomly oriented muscovite aggregates (Fig. 2f). The $\mathrm{S}_{3}$ foliation is observed only within, or adjacent to, the shear zone and is defined by reoriented muscovite and/or appearance of new chlorite.

Rare quartz-grossular symplectites, rimming wollastonite grains in calc-silicate rocks, have been interpreted as a result of retrogression, similar to the veins with younger vesuvianite porphyroblasts. Fluid inclusions in vesuvianite porphyroblasts indicate a temperature of $340-440^{\circ} \mathrm{C}$ at a pressure of $0.2 \mathrm{GPa}$ (Fig. 8). The presence of carbonic fluids in vesuvianite corresponds to the interaction between water and graphite in the surrounding graphite-bearing metapelites. The $\mathrm{CH}_{4}$ content depends on the redox conditions during the terminal stage of the contact metamorphism. No influence of methane on the mineral equilibria was considered. However, other additional components in the fluids may have strongly affected the mineral equilibria. For example, the high $\mathrm{F}$ content shifts the reaction curves involving vesuvianite to higher $\mathrm{X}_{\mathrm{CO} 2}$ values (Dúzs-Moore et al. 2003).

Published numerical simulations for intrusions of granitoid plutons into the metasedimentary lithologies (Nabelek 2007, 2009) showed complex evolution of mixed $\mathrm{CO}_{2}-\mathrm{H}_{2} \mathrm{O}$ fluids coexisting with marbles. Wollastonite-rich rocks occur in narrow zones next to the contact with granitoids, having been formed as a consequence of a magmatic fluid infiltration. The models predict initial rapid heating and increasing $\mathrm{X}_{\mathrm{CO}_{2}}$ in the fluid phase from the wollastonite zone. The maximum $\mathrm{X}_{\mathrm{CO}_{2}}$ in the fluids is attained during the diopside-producing reaction, because diopside is formed directly from dolomite. The $\mathrm{T}-\mathrm{X}_{\mathrm{CO}_{2}}$ paths after formation of diopside indicate only a small increase in temperature but decreasing $\mathrm{X}_{\mathrm{CO}_{2}}$ in the coexisting fluids. Wollastonite began to be produced due to massive infiltration of magmatic fluid during cooling of the magmatic bodies. This model can be used for interpretation of the $\mathrm{T}-\mathrm{X}_{\mathrm{CO}_{2}}$ paths for the studied calc-silicate rocks (Fig. 7). However, in this case wollastonite grew near the temperature peak and most of the vesuvianite was produced during cooling of the contact aureole.

The presence of grossular- and quartz-bearing veinlets crosscutting vesuvianite porphyroblasts can be interpreted as a result of a younger fluid pulse. 


\subsubsection{Post-metamorphic brittle deformation $\left(D_{4}\right)$}

The youngest deformation phases produced brittle faults oriented predominantly NW-SE and SW-NE.

\section{Conclusions}

The Dipilto Batholith is a NE-SW elongated body intruded into the metasediments of the Eastern Chortis Terrane. The composition of the plutonic rocks ranges from amphibole-biotite tonalite to biotite granite or granodiorite and subordinate amphibole gabbro to diorite. Three distinct metamorphic phases were distinguished in the studied Jalapa area.

The first phase was represented by greenschist-facies regional metamorphism $\left(\mathrm{M}_{1}\right)$ accompanied by prograde deformation $\left(D_{1}\right)$.

The Cretaceous intrusion of the granitoids of the Dipilto Batholith was associated with contact metamorphism of the wall-rock schist $\left(\mathrm{M}_{2}\right)$. Thermobarometric calculations from the amphibole-biotite granitoids $\left(629-727^{\circ} \mathrm{C}\right.$, 0.1-0.2 GPa) are consistent with the mineral assemblage of the contact metamorphic rocks (estimated P-T conditions $500-650^{\circ} \mathrm{C}$ and $\sim 0.2 \mathrm{GPa}$ ). During the contact metamorphism, andalusite and/or cordierite porphyroblasts crystallized in metapelites. The mineral assemblage of the metapelite matrix is $\mathrm{Bt}+\mathrm{Qtz}+\mathrm{Ab}+\mathrm{Gr} \pm \mathrm{Chl} \pm$ $\mathrm{Ms} \pm \mathrm{Kfs}$ having been influenced by several factors: the chemical composition, the presence of graphite in the metamorphic rocks and the distance from the contact. Calc-silicate rocks preserve the peak-metamorphic $\left(\mathrm{M}_{2}\right)$ mineral assemblage $\mathrm{Wo}+\mathrm{Di}+\mathrm{Grs}+\mathrm{Ves}+\mathrm{Qtz}+\mathrm{Pl}+$ $\mathrm{Kfs}$. Wollastonite and grossular grew at temperatures of $500-600{ }^{\circ} \mathrm{C}$, after interaction with water-rich fluids generated during crystallization of the shallowly $(0.2$ $\mathrm{GPa}$ ) intruded Dipilto Batholith. The emplacement of the pluton was locally accompanied by a weak deformation of metasediments $\left(\mathrm{D}_{2}\right)$.

During cooling and exhumation, the contact aureole around the Dipilto Batholith was affected by retrograde metamorphism $\left(\mathrm{M}_{3}\right)$ of largely static character. Secondary minerals (chlorite, muscovite) in the metapelites locally replaced biotite, cordierite and andalusite. During this metamorphic phase, wollastonite was partly replaced by grossular-rich garnet and vesuvianite porphyroblasts, which grew under relatively low temperatures of $400-500^{\circ} \mathrm{C}$. The microthermometric analyses of fluid inclusions from vesuvianite indicate that the fluid contained predominantly water with minor proportion of $\mathrm{CH}_{4}$ and $\mathrm{NaCl}$ (88.9-93.8 mol. \% water, 3.4-9.9 mol. \% methane and $1.2-2.8 \mathrm{~mol} . \% \mathrm{NaCl}$ ). Methane was probably generated through interaction of water-rich fluids with the surrounding graphite-bearing metapelites under reducing conditions. During a later stage of this metamorphic event, young garnet filled fractures in vesuvianite. Deformation events $\mathrm{D}_{3}$ and $\mathrm{D}_{4}$ resulted in local development of shear zones and brittle faults.

Acknowledgements. The authors would like to thank Uwe Martens, Arne Willner and Petr Dobeš for critical reviews of the manuscript. Petr Gadas is thanked for assistance with the electron microprobe. Last but not least, the careful editorial handling by Jana Kotková helped us to improve the readability of the text. This work was carried out with the financial support of the project of geological mapping of high-risk processes in Nicaragua, provided by the Czech Geological Survey in cooperation with the Instituto Nicaragüense de Estudios Territoriales (INETER) in 2007-2009 and also with the financial support of the project of the Czech Science Foundation No. 205/07/P130.

\section{References}

Allen PA, Allen JR (1990) Basin analysis: principles and applications. Wiley and Blackwell, Oxford, pp 1-451

Anderson JL, SMith DR (1995) The effects of temperature and $\mathrm{fO}_{2}$ on the Al-in-hornblende barometer. Amer Miner 80: $549-559$

BAKKER RJ (2003) Package FLUIDS 1. Computer programs for analysis of fluid inclusion data and for modelling bulk fluid properties. Chem Geol 194: 3-23

Blandino B (2006) Petrography of metamorphic rocks from Macuelizo, Nueva Segovia (Nicaragua). Unpublished MSci. thesis, Universidad Nacional Autónoma de Nicaragua, Managua, pp 1-124 (in Spanish)

Buick I, Holland T (1991) The nature and distribution of fluids during amphibolite facies metamorphism, Naxos (Greece). J Metamorph Geol 9: 301-314

Buriánek D, Hradecký P, Havlíček P, ČÁp P, Novotný R, BALDík V (2010) Geological map of Jalapa area 1:50 000. Czech Geological Survey, Prague (in Czech)

Case J, MacDonald W, Fox P (1990) Caribbean crustal provinces; seismic and gravity evidence. In: Dengo G, CASE JE (eds) The Caribbean Region. Geological Society of America, Boulder, CO, pp 15-36

Collins PLF (1979) Gas hydrates in $\mathrm{CO}_{2}$-bearing fluid inclusions and the use of freezing data for estimation of salinity. Econ Geol 74: 1435-1444

Connolly JAD (1990) Multivariable phase diagrams; an algorithm based on generalized thermodynamics. Amer J Sci 290: 666-718

Connolly JAD, Cesare B (1993) C-O-H-S fluid composition and oxygen fugacity in graphitic metapelites. J Metamorph Geol 11: 379-388 
Crespo E, Luque J, Fernandez-Rodriguez C, Rodas M, Diaz-Azpiroz, M, Fernandez-Caliani JC, Barrenechea JF (2004) Significance of graphite occurrences in the Aracena Metamorphic Belt, Iberian Massif. Geol Mag 141: 687-697

Del Giudice D (1960) Notes on the geology of the Department of Nueva Segovia. Bol Serv Geol Nac Nicaragua 4: 17-37 (in Spanish)

Dengo G (1969) Problems of tectonic relations between Central America and the Caribbean. Gulf Coast Assoc Geol Soc Trans 19: 311-320

Donnelly TW, Horne GS, Finch RC, López-Ramos E (1990) Northern Central America: The Maya and Chortís blocks. In: Dengo G, CASE JE (eds) The Caribbean Region. Geological Society of America, Boulder, CO, pp 37-36

Droop GTR (1987) A general equation for estimating $\mathrm{Fe}^{3+}$ concentrations in ferromagnesian silicates and oxides from microprobe analyses, using stoichiometric criteria. Mineral Mag 51: 431-435

Dúzs-Moore A, Leavens PB, Jenkins IRE, Altounian NM (2003) Wollastonite at the Sterling Hill Fe-Zn-Mn ore body, Ogdensburg, New Jersey. Mineral Petrol 79: 225-241

Dyadin YuA, Larionov EG, Aladko EYa, Zhurko FV (2001) Clathrate nitrogen hydrates at pressures of up to 15 kbar. Dokl Phys Chem 378: 653-655

ENGELs B (1964) Geologische Problematik und Structuranalyse Nikaraguas. Geol Rundsch 54: 758-795

Ferry JM, Wing BA, Rumble D (2001) Formation of wollastonite by chemically reactive fluid flow during contact metamorphism, Mt. Morrison Pendant, Sierra Nevada, California, USA. J Petrol 42: 1705-1728

FIGGE K (1966) Die stratigraphische Stellung der metamorphen Gesteine NW-Nicaraguas. Neu Jb Geol Paläont, Mh 4: 193-254 (in German)

Gerdes ML, Valley JW (1994) Fluid flow and mass transport at the Valentine wollastonite deposit, Adirondack Mountains, New York State. J Metamorph Geol 12: 589-608

Hochella MF, Liou JG, Keskinen MJ, Kim HS (1982) Synthesis and stability relations of magnesium idocrase. Econ Geol 77: 798-808

HodGSON G (2000) Introduction to Nicaragua stratigraphy. Unpublished PhD. thesis, Universidad Nacional Autónoma de Nicaragua, Managua, pp 1-184 (in Spanish)

Holland T, BLundy J (1994) Non-ideal interactions in calcic amphiboles and their bearing on amphibole-plagioclase thermometry. Contrib Mineral Petrol 116: 433-447

Holland TJB, Powell R (1990) An enlarged and updated internally consistent thermodynamic dataset with uncertainties and correlations; the system $\mathrm{K}_{2} \mathrm{O}-\mathrm{Na}_{2} \mathrm{O}-\mathrm{CaO}-$ $\mathrm{MgO}-\mathrm{MnO}-\mathrm{FeO}-\mathrm{Fe}_{2} \mathrm{O}_{3}-\mathrm{Al}_{2} \mathrm{O}_{3}-\mathrm{TiO}_{2}-\mathrm{SiO}_{2}-\mathrm{C}-\mathrm{H}_{2}-\mathrm{O}_{2}$. J Metamorph Geol 8: 89-124
Holland TJB, Powell R (1998) An internally consistent thermodynamic data set with uncertainties and correlations: the system $\mathrm{Na}_{2} \mathrm{O}-\mathrm{K}_{2} \mathrm{O}-\mathrm{CaO}-\mathrm{MgO}-\mathrm{MnO}-\mathrm{FeO}-$ $\mathrm{Fe}_{2} \mathrm{O}_{3}-\mathrm{Al}_{2} \mathrm{O}_{3}-\mathrm{SiO}_{2}-\mathrm{TiO}_{2}-\mathrm{C}-\mathrm{H}_{2}-\mathrm{O}_{2}$. J Metamorph Geol 8: $89-124$

Hradecký P, Kycl P, Žáček V, Hrazdíra P, Opletal M, ŠEvČíK J, ŠEBESTA J (2005) Geological study of the natural hazards in the Ocotal area, Nueva Segovia province, Nicaragua. Unpublished manuscript, Czech Geological Survey, Prague, pp 1-84 (in Czech)

JANOUŠEK V, FARROW CM, ERBAN V (2006) Interpretation of whole-rock geochemical data in igneous geochemistry: introducing Geochemical Data Toolkit (GCDkit). J Petrol 47: 1255-1259

KRETZ R (1983) Symbols for rock-forming minerals. Amer Miner 68: 277-279

Leake BE, Wooley AR, Arps CES, Birch WD, Gilbert MC, Grice JD, Hawthorne FC, Kato A, Kisch HJ, KrivoviCHEV VG (1997) Nomenclature of amphiboles: report of the Subcommittee on Amphiboles of the International Mineralogical Association Commission on New Minerals and Mineral Names. Canad Mineral 35: 219-237

Martens U, Ortega-Obregón C, Estrada J, Valle M (2007) Metamorphism and metamorphic rocks (Chapter 19). In: Bundschun J, Alvaredo GE (eds) Central America: Geology, Resources and Hazards. Taylor and Francis, London, pp 489-526

Morimoto N, Fabries J, Ferguson AK, Ginzburg IV, Ross M, Seifert FA, Zussman J, Aoki K, Gottardi G (1988) Nomenclature of pyroxenes. Amer Miner 73: 1123-1133

NABELEK PI (2007) Fluid evolution and kinetics of metamorphic reactions in calc-silicate contact aureoles - from $\mathrm{H}_{2} \mathrm{O}$ to $\mathrm{CO}_{2}$ and back. Geology 35: 927-930

NABELEK PI (2009) Numerical simulation of kineticallycontrolled calc-silicate reactions and fluid flow with transient permeability around crystallizing plutons. Amer J Sci 309: 517-548

Newton RC, Charlu TV, Kleppa OJ (1980) Thermochemistry of the high structural state plagioclases. Geochim Cosmochim Acta 44: 933-941

Ortega-Gutiérrez F, Solari LA, Ortega-Obregón C, Elías-Herrera M, Martens U, Morán-Icál S, Chiquín M, Keppie JD, Torres de León R, SchaAf P (2007) The Maya-Chortís boundary: a tectonostratigraphic approach. Int Geol Rev 49: 996-1024

Pattison DRM, Spear FS, Debuhr CL, Cheney JT, Guidotti CV (2002) Thermodynamic modelling of the reaction muscovite + cordierite $\rightarrow \mathrm{Al}_{2} \mathrm{SiO}_{5}+$ biotite + quartz + $\mathrm{H}_{2} \mathrm{O}$ : constraints from natural assemblages and implications for the metapelitic petrogenetic grid. J Metamorph Geol 20: 99-118

Quintero-Román R (2006) Geological study of the contact metamorphism, San Fernando, Nuevo Segovia (Nicaragua). Unpublished MSci. thesis, Universidad 
Nacional Autónoma de Nicaragua, Managua, pp 1-90 (in Spanish)

RitchiE AW, Finch RC (1985) Widespread Jurassic strata on the Chortis Block of the Caribbean Plate. Geological Society of America Abstracts with Programs, 17: 700-701

RoEdDER E (1984) Fluid Inclusions. Mineralogical Society of America Reviews in Mineralogy 12: 1-644

Rogers RD (2003) Jurassic-Recent tectonic and stratigraphic history of the Chortis Block of Honduras and Nicaragua (northern Central America). Unpublished PhD. thesis, University of Texas, Austin, pp 1-289

Rogers RD, Mann P, Emmet PA (2007a) Tectonic terranes of the Chortis Block based on integration of regional aeromagnetic and geologic data. In: MANN P (ed) Geologic and Tectonic Development of the Caribbean Plate Boundary in Northern Central America. Geological Society of America Special Papers 428: 65-88

Rogers RD, Mann P, Emmet PA, Venable M.E. (2007b) Colon fold belt of Honduras: evidence for Late Cretaceous collision between the continental Chortis Block and intraoceanic Caribbean Arc. In: MANN P (ed) Geologic and Tectonic Development of the Caribbean Plate Boundary in Northern Central America. Geological Society of America Special Papers 428: 129-149

Rossetti F, Tecce F, Billi A, Brilli M (2007) Patterns of fluid flow in the contact aureole of the Late Miocene
Monte Capanne Pluton (Elba Island, Italy) the role of structures and rheology. Contrib Mineral Petrol 153: 743-760

ShePherd TJ, RANKIn AH, Alderton DHM (1985) A Practical Guide to Fluid Inclusion Studies. Blackie, Glasgow and London, pp 1-239

SchmidT MW (1993) Phase relations and compositions in tonalite as a function of pressure: An experimental study at $650^{\circ} \mathrm{C}$. Amer J Sci 293: 1011-1060

Venable M (1994) A geological, tectonic, and metallogenetic evaluation of the Siuna Terrane (Nicaragua). Unpublished PhD. thesis, University of Arizona, Tucson, pp 1-154

Viland JC, Henry B, Calix R, Diaz C (1996) Late Jurassic deformation in Honduras. Proposals for a revised regional stratigraphy. J South Am Earth Sci 9: 153-160

ZopPIs-Bracci L (1957) Geological study of the Palacagüina region and its antimony deposits. Bol Serv Geol Nac Nicaragua 1: 29-34 (in Spanish)

Zoppis-Bracci L, Del Giudice D (1961) Preliminary study of tungsten and molybdenum mineralization Macuelizo, Departament of Nueva Segovia. Bol Serv Geol Nac Nicaragua 5: 33-52 (in Spanish)

Ž́́ČEK V, HRADECKÝ P (2005) Geological map of Ocotal area (Nikaragua) 1:50 000. Czech Geological Survey, Prague (in Czech) 